Swiss Finance Institute
Research Paper Series N¹5-10

\title{
Central Bank Collateral Frameworks
}

Kjell G. NYBORG

University of Zurich, Swiss Finance Institute, and CEPR 


\title{
Central Bank Collateral Frameworks ${ }^{1}$
}

\author{
Kjell G. Nyborg \\ University of Zurich, \\ Swiss Finance Institute, \\ and CEPR
}

February 2015

\begin{abstract}
${ }^{1}$ This paper has been written in parallel with a larger (book) manuscript, cited as Nyborg (2015), and provides a summary of some of the ideas and findings in that larger manuscript. Thus, the majority of the text in this paper is shared verbatim with that of the larger manuscript, though the order of passages may be different. The research sampled here has been a large undertaking and I would like to thank Lilia Mukhlynina, Cornelia Rösler, and Jiri Woschitz for research assistance. The responsibility for any errors is mine. I have also benefited from comments from participants at the ECB Workshop on "Structural changes in money markets: Implications for monetary policy implementation" (September 2013) and a seminar at the Central Bank of Ireland (April 2014). Address: Department of Banking and Finance, University of Zurich, Plattenstrasse 14, 8032 Zurich, Switzerland. E-mail: kjell.nyborg@bf.uzh.ch.
\end{abstract}

(C) Kjell G. Nyborg 


\section{Abstract \\ Central Bank Collateral Frameworks}

This paper seeks to inform about a feature of monetary policy that is largely overlooked, yet occupies a central role in modern monetary and financial systems, namely central bank collateral frameworks. Their importance can be understood by the observation that the money at the core of these systems, central bank money, is injected into the economy on terms, not defined in a market, but by the collateral frameworks and interest rate policies of central banks. Using the collateral framework of the Eurosystem as a basis of illustration and case study, the paper brings to light the functioning, reach, and impact of collateral frameworks. A theme that emerges is that collateral frameworks may have distortive effects on financial markets and the wider economy. They can, for example, bias the private provision of real liquidity and thereby also the allocation of resources in the economy as well as contribute to financial instability. Evidence is presented that the collateral framework in the euro area promotes risky and illiquid collateral and, more generally, impairs market forces and discipline. The paper also emphasizes the important role of ratings and government guarantees in the Eurosystem's collateral framework.

Keywords: central bank, banks, collateral, money, liquidity, monetary system, financial system, monetary policy, ratings, guarantees, haircuts, Eurosystem, ECB JEL: E58, E42, E52, E44, G10, G01, G21 
Money is economical power.

- Walter Bagehot (1873)

\section{Introduction}

If money is economic power and money is issued against collateral, it follows that it is important to understand the nature of the collateral and the terms of the exchange. The money at the core of modern economies is central bank money, what bankers call liquidity. This is injected into the economy, through banks as intermediaries, on terms not defined in a market, but by the collateral frameworks and interest rate policies of central banks. In some jurisdictions, or currency areas, central bank independence means that collateral frameworks are not subject to formal supervision, review, or even much by way of discussion. Public focus has instead been directed towards interest rates or monetary aggregates. There is also a dearth of academic focus on central bank collateral policies. Collateral frameworks are largely shrouded in opacity. This paper therefore aims to bring to light the functioning, reach, and impact of collateral frameworks.

A central bank's collateral framework is a part of its monetary policy. It is commonly accepted that monetary policy affects the wider economy. There is also emerging evidence that there are monetary effects in financial markets. However, most work on these topics look at broad brush policy variables such as short term interest rates or the quantity of money. There is little work that studies the micro-foundation of the monetary system and its impact on markets and the economy. Learning more about collateral frameworks contributes towards filling that gap. This is important in light of the ongoing challenges in the global economy, where central banks are engaged in quantitative easing and other forms of unconventional monetary policy in an effort to stabilize and support the economy, banks, and the financial markets. In the euro area, monetary policy is even in the vanguard in the fight to save the euro and European project itself. The collateral framework of the Eurosystem is an integral part of that effort. ${ }^{1}$

\footnotetext{
${ }^{1}$ See Nyborg (2015) for further discussion on this point. The Eurosystem is the collective structure of national central banks in the euro area spearheaded by the European Central Bank (ECB).
} 
Banking and finance are central to the broader economy because money flows through the banking sector and the financial system. A better understanding of how this works requires in the first instance a deeper and more detailed knowledge of monetary system architecture. While central bank working groups have issued reports on collateral frameworks (e.g., Cheun, von Köppen-Mertes, and Weller, 2009; BCBS, 2013b), these are overviews that do not go into depth with respect to how these frameworks actually function or what their broader consequences may be. A theme that will emerge in this paper is that collateral frameworks may have distortive effects on financial markets and the wider economy.

Different central banks have different collateral frameworks. There are common features, but details can vary a great deal. The focus in this paper is on the framework of the Eurosystem, which the ECB is authorized to design and update (ECB, 2000/7). This is an especially interesting case to study because of the richness and complexity that arise from a single currency across multiple countries and the very wide range of collateral banks can use to obtain central bank money directly from the Eurosystem. The euro area also represents one of the largest economies in the world. Its well publicized financial, economic, and political problems have significant impact on global markets and the world economy. Concerns about the euro itself are intermingled with, and, arguably, at the core of these problems. Gaining a more sound understanding of the euro area's monetary system at the most fundamental level is therefore of great value.

The rest of this paper is organized as follows. Section 2 provides background on the market for liquidity and its influence on, and relation to, the broader financial markets. This includes a brief discussion of the severe problems in these markets during the financial crisis and the expansion in central bank balance sheets that resulted from the unconventional monetary policies pursued to deal with the crisis. Since larger balance sheets means more money being created against more collateral of potentially questionable quality, this illustrates the growing importance of collateral and central bank collateral frameworks. But the significance of collateral frameworks is not limited to the crisis.

The general importance of collateral frameworks is discussed in Section 3, with an emphasis on the potential costs that can arise from collateral framework design. I argue that collateral frameworks can influence and distort financial markets and the real economy. Section 3 also sheds light on how collateral frameworks 
work in practice by describing central features of the framework used in the euro area. I provide evidence that the Eurosystem's collateral framework promotes lower quality (more risky and illiquid) collateral and also touch on the important role of ratings and guarantees. Further details, both in terms of the legal rules of the Eurosystem's collateral framework and empirical facts shedding light on how it works in practice, is provided by Nyborg (2015).

One of the implications of the findings presented in Section 3 is that the Eurosystem's collateral framework undermines market discipline. This is the topic of Section 4. Section 5 concludes.

\section{Background}

There is an enormous amount of work on monetary policy transmission channels. This paper complements and contributes to that literature, but does not emanate from it. Instead, it can be characterized as the product of the literatures on the market for liquidity, monetary effects in financial markets, collateral, and financial intermediation. With respect to the first of these, what is especially relevant for this paper is the literature that studies open market operations and the interaction of banks and the central bank. I will touch on this in subsection 2.2. Collateral is discussed towards the end of this section and the most relevant literature on financial intermediation is touched on in the next section. I start here by briefly discussing the evidence on monetary effects in financial markets from a rather "selfish" perspective.

\subsection{Money matters in financial markets}

Work I have done with Per Östberg on the details of the interaction between the market for liquidity and the broader financial markets shows that money matters in financial markets in part because frictions in interbank markets spill over into the broader markets through what we call liquidity pull-back (Nyborg and Östberg, 2014). There is also evidence that asset prices and measures of liquidity in financial markets are affected by monetary shocks (see, e.g., Fleming and Remolona, 1997; Fair, 2002; Flannery and Protopapadekis, 2002; Bernanke and Kuttner, 2005; Chordia, Sarkar, and Subrahmanyam, 2005). Liquidity pull- 
back is a monetary phenomenon acted out in financial markets. It is based on the important role played by central bank money in modern banking and financial systems. Central bank money is the currency, or liquidity, banks need to satisfy reserve requirements, allow for depositor withdrawals, settle interbank transactions, etc. It is injected into the banking system through central bank operations and then reallocated among banks. For many transactions, there is no substitute for central bank money. Thus, for any bank, having sufficient central bank money at any point in time is a binding constraint.

However, conditions in the interbank market may fluctuate. At times it may be "tight," in the sense that the price of liquidity is high and some banks may have exhausted interbank credit limits. If so, banks may seek alternative sources of central bank money. But as observed by Friedman (1970): "One man can reduce his nominal money balances only by persuading someone else to increase his." The same holds true for banks. Friedman's observation is echoed by Tobin (1980): "The nominal supply of money is something to which the economy must adapt, not a variable that adapts itself to the economy - unless the policy authorities want it to." These restriction can be overcome by borrowing from the central bank's lending facility (discount window), but this is expensive. A bank can also attempt to attract new, or retain old, deposits, but this is a slow process. Liquidity pull-back offers an alternative approach, namely to obtain liquidity through interacting with financial markets; by pulling liquidity back from them.

This can be done several ways, most obviously by selling financial assets directly. ${ }^{2}$ The mechanism within a bank through which this may happen is that the bank's internal liquidity management system feeds into trading desks' limits, reducing them. Alternatively, liquidity pull-back can be achieved by increasing margins to levered investors or haircuts in repos (repurchase agreements). Liquidity pull-back does not increase the quantity of central bank money in the system. However, the actions I have described can increase the selling (or acting) bank's liquidity balances, as long as the (ultimate) buyer banks with another bank.

Östberg and I emphasize that a feature of the theoretical idea we sketch in our paper is that financial assets serve as a storage facility for liquidity that a bank can tap into if it should face a shortfall. We draw out the implications of this idea with respect to effect of interbank tightness on volume, order flow,

\footnotetext{
${ }^{2}$ See, e.g., Kashyap and Stein (2000) for evidence on banks' holdings of securities.
} 
and returns in the broader financial markets. The empirical evidence is strongly supportive.

Nyborg and Östberg (2014) thus show that the way banks obtain central bank money affects financial markets. This supports the perspective in the current paper that collateral frameworks matter, since they determine the terms at which banks can obtain liquidity directly from the central bank. The process of allocating central bank money in the economy starts with the interaction of central banks vis-à-vis banks and this interaction needs to obey the rules and constraints imposed by the central bank's collateral framework.

\subsection{The market for liquidity}

Before the crisis, money markets were viewed by many academics and policy makers alike as unimportant for the broader financial markets and the economy. This is not because they were thought of as not serving an important function, but because they were regarded as functioning extremely well. They were considered to be highly competitive and liquid - in a word, "boring" - with no significant impact on the broader financial markets. Yet, the money markets literature shows that this view was never quite correct.

Hamilton's (1996) seminal study finds that the Fed funds rate (US overnight rate) reacts to calendar effects relating to the reserve maintenance period. There is also evidence that the overnight rate reacts to the supply of reserves (Hamilton, 1997; Carpenter and Demiralp, 2006). Similar effects can be found in the euro area (e.g., Nautz and Offermanns, 2007; Angelini, 2008; and Beirne, 2012). Fecht, Nyborg, and Rocholl (2008) and Rösler (2015) also document calendar effects with respect to volume. These findings are indications of a less than perfect market for liquidity. Furthermore, using primary market data from ECB main refinancing operations (repo auctions) well before the crisis, Bindseil, Nyborg, and Strebulaev (2009) find evidence that the market for liquidity in the euro area is informationally efficient, but at the same time allocationally inefficient.

The existence of inefficiencies in the market for liquidity explains the positive support in the data for the liquidity pull-back idea. Indeed, that work was motivated by the empirical evidence that interbank markets are not efficient, even during times of normalcy. An earlier ECB working paper by Nyborg, Bindseil, and Strebulaev (2002) also finds evidence consistent with the idea that the collat- 
eral framework affects banks' willingness to pay for liquidity. In particular, these authors conclude that eurozone banks are not indifferent as to what collateral they use in transactions with the Eurosystem. After the onset of the financial crisis in August 2007, the significance of the market for liquidity and collateral has become greatly magnified, as will be explained below.

\subsection{The financial crisis and unconventional monetary pol- icy}

A central (and much studied) aspect of the financial crisis is the emergence of severe frictions in the interbank market for liquidity. Interestingly, therefore, Nyborg and Östberg (2014) find that the liquidity pull-back effect as a day-today phenomenon became weaker, or harder to identify. A potential explanation for this is that the financial crisis represented a massive liquidity pull-back event, where money and securities as close as possible to money (e.g., treasury bills) were sought by investors and banks and the day-today liquidity pull-back effect was dwarfed by the much larger pattern of the crisis (think fractals). In addition, the large injections by central banks of liquidity in response to the crisis eventually made it less necessary for banks to engage in liquidity pull-back. Instead, they could post collateral to the central bank and receive liquidity directly that way.

While the market for liquidity did not stop functioning during the crisis, it functioned less well than before (see, e.g., Cassola, Holthausen, and Lo Duca, 2010, for the euro area and Afonso, Kovner, and Schoar, 2011, for the US.) Dysfunction in the market for liquidity was a central feature of the crisis. The price of liquidity shot up (Figure 1) while volume shifted in from longer to shorter maturities and fell overall (Abbassi, Bräuning, Fecht, and Peydró, 2014; Gabrieli and Georg, 2015; and Rösler, 2015). The turmoil in the interbank market for liquidity was accompanied by a massive loss of value in asset prices. This is illustrated in Figure 1, using equities as an example. While Figure 1 uses euro area data, graphs using corresponding data from other markets (e.g., the US) would look the same.

\section{Insert Figure 1 here.}

Figure 1 plots the spread between the 3-month Euribor and 3-month Eonia 
swap rates (Euribor-Eonia spread), with values on the right-axis, and a broad euro area stock market index (Euro Stoxx), with values on the left axis. As explained by Nyborg and Östberg (2014), while the Euribor-Eonia spread may reflect credit risk, it represents more directly the price of liquidity (here, over three months). A high spread is tantamount to the interbank market for liquidity not working well. The sharp increase in the spread in August 2007 represents the beginning of the financial crisis. The spread is seen to peak just after the time of the Lehman bankruptcy, which occurred on September 15, 2008. That the bankruptcy of a US institution should trigger a severe tightening in the market for liquidity in the euro area illustrates the interconnectedness of global markets. Since then, the spread has come substantially down, though not quite to pre-crisis levels.

The pattern for the stock market is analogous. As the interbank market for liquidity saw severe tightening, the stock market almost collapsed, losing around $50 \%$ of its value from August 2007 to the bottom in March 2009. Since then the euro area stock market has reversed, gaining back much of the lost ground. Stock markets around the world reacted similarly.

In response to the stressed conditions that ensued after Lehman Brothers' bankruptcy, the ECB made significant changes to its monetary operations. On October 8, 2008, the ECB announced that it would switch from auctioning a limited quantity of liquidity in its operations to running fixed rate tenders at the policy rate with full allotment. It would do this for both the main and longer term refinancing operations (MROs and LTROs, respectively). This represents one of the most significant actions taken by the ECB in response to the crisis. Under full allotment, central bank money is not rationed in the refinancing operations, as it used to be under the old liquidity neutral policy. ${ }^{3}$ Instead, banks receive everything they ask for. The only restriction is that they have to pledge sufficient collateral to cover these amounts. What sufficient means is governed by the Eurosystem's collateral framework.

Until October 2008, LTRO money was available with three-month maturities. After the introduction of the full allotment policy, further problems in the euro area led to a lengthening of LTRO maturities to one and three years. In total, in the two three-year LTROs, held in December 2011 and February 2012, banks asked for, and received, more than EUR 1 trillion.

\footnotetext{
${ }^{3}$ See, e.g., Bindseil, Nyborg, and Strebulaev (2009).
} 
Unlimited amounts of three year money was not enough to calm the markets. The threat to the euro was real enough to move Mario Draghi, President of the European Central Bank, to make his famous declaration in July 2012 that "Within our mandate, the ECB is ready to do whatever it takes to preserve the euro." 4

On September 6, 2012, this was followed up by the launch of the Outright Monetary Transactions programme (OMT). ${ }^{5}$ The OMT allows for unlimited, sterilized purchases of sovereign bonds of countries under a European Financial Stability Facility/European Stability Mechanism program, but has as of January 2015 yet to be employed. Even so, it is often viewed as representing the "whatever it takes" in Draghi's famous statement quoted above.

But the problems in the eurozone did not go away after the OMT, as evidenced, for example, by the continued use of the full allotment policy in open market operations and ongoing considerations of further unconventional measures. ${ }^{6}$ The mere promise of unlimited purchases of troubled sovereigns' paper (the OMT) was not enough. Real action was required. Thus, on September 4, 2014, the ECB announced asset backed security (ABS) and covered bond purchase programs that, at the time, were said to possibly add as much as one trillion to the balance sheet of the Eurosystem. The exact quantity was subject to much speculation, but reconfirmed in December 2014 and then again in January 2015, when Draghi finally announced that the Eurosystem would go the extra mile and start buying sovereign bonds, though not under the OMT but as a part of the broader ca. one trillion asset purchase program announced in September 2014. Asset purchases also relate to the collateral framework because it governs, among other things, what the set of eligible assets are.

\footnotetext{
${ }^{4}$ See "Speech by Mario Draghi at the Global Investment Conference in London 26 July 2012," http://www.ecb.europa.eu/press/key/date/2012/html/sp120726.en.html.

${ }^{5}$ See ECB Press Release on 6 September 2012 - Technical features of Outright Monetary Transactions, http://www.ecb.europa.eu/press/pr/date/2012/html/pr120906_1.en.html.

${ }^{6}$ See, e.g., "Monetary policy communication in turbulent times," Speech by Mario Draghi, President of the ECB, at the Conference De Nederlandsche Bank 200 years: Central banking in the next two decades, Amsterdam, 24 April 2014, http://www.ecb.europa.eu/press/key/date/2014/html/sp140424.en.html.
} 


\subsection{Central bank balance sheets and the increasing im- portance of collateral}

The accommodative monetary policies of central banks in response to the financial crisis have substantially increased their balance sheets. This is illustrated in Figure 2.

\section{Insert Figure 2 here.}

Figure 2a shows the growth in the consolidated balance sheet of the Eurosystem and, by way of comparison, six other central banks, the Federal Reserve System, Bank of Japan, Bank of China, Bank of Canada, Bank of England, and Norges Bank (Norway), ${ }^{7}$ over the period 2000 to 2014 . The data are for the end of each calendar year, except 2014 when the sizes of the balance sheets are taken at the end of June. For each central bank, each year is benchmarked against its 2004 balance sheet, which represents 100\%. The variation in balance sheet growth across these countries is quite large. For example, over the 2004 to 6/2014 period, it ranges from less than $100 \%$ for the Banks of Japan, Canada, and Norway to approximately $800 \%$ for the Bank of England (which, because of this very large increase, gets its own axis in the plot). The Eurosystem is in the middle, with an increase of $115 \%$.

Figure $2 \mathrm{~b}$ plots the size of the balance sheets as a percentage of the respective countries' (or currency area's) GDP, from 2000 to 2013. The Eurosystem's balance sheet has increased from around 12\% of euro area GDP in 2002 to around $24 \%$ in 2013. This is approximately the same percentage in 2013 as for the Bank of China and the Fed, but less than Banks of England (30\%) and Japan (47\%). A balance sheet to GDP ratio of more than $20 \%$ is unprecedented before the crisis over the period sampled here for these countries, with the exception of the Banks of Japan and China. This illustrates the rising importance of central banks and, by implication, the assets they hold.

Central bankers are concerned that the growth in central bank balance sheets over the crisis is associated with these getting weaker as a result of ever worse collateral being taken on. For example, Thomas Jordan, President of the Swiss

\footnotetext{
${ }^{7}$ For the Norges Bank figures, the contribution of the "petroleum fund" to the balance sheet is excluded.
} 
National Bank, is on record as saying that "[a]s a result of the measures implemented during the crisis, central banks took much more risk onto their balance sheets, which could potentially lead to substantial losses" and "[t]here is no doubt that central banks have to play a role in an economic crisis at the market level as well as at the level of individual systemically important banks. In order to act appropriately, they need room to maneuver, which implies a sound central bank balance sheet with sufficient equity" (Jordan, 2012). These sentiments are echoed by Klaas Knot (2013), Governor of the Dutch Central Bank,

The unprecedented expansion of central banks' balance sheet since the start of the crisis is certainly revealing. It shows that central banks' balance sheets are becoming more and more exposed to economic risk and political pressure. Eventually, this may result in a substantial amount of negative capital in a central bank's balance sheet. This is undesirable, because it could undermine a central bank's credibility and independence...An additional concern for central banks is that unconventional monetary policy increasingly comes with some sense of 'public unease' about the role central banks play...The fact that criticism of central banks is creeping more and more into the mainstream debate - whether or not this is justified - implies that the public is looking increasingly critically at central banks. While this may not put central bank independence or central banks' room for maneuver immediately at risk, it does signify that central banks may need to step up their efforts on transparency and accountability.

The assets, or collateral, these central bankers are speaking of - that they have absorbed into their balance sheets over the course of the crisis - and that they are justly concerned about, is a consequence of the functioning of the collateral frameworks that central banks themselves have designed and the unconventional monetary policies they have pursued. The quotes above are therefore testament to the importance of collateral frameworks. It is also suggestive of something being not quite right about them. The central bankers seem to imply that their collateral frameworks could be a source of risk that could create problems down the road. 


\subsection{Collateral}

The discussion above points to the centrality of collateral with respect to monetary policy and the market for liquidity. Because conditions in the market for liquidity spill over to the broader financial markets, collateral and collateral frameworks also matter for financial markets. Furthermore, collateral is now more important than ever, in part because of the growth in central bank balance sheets and in part because there is a regulatory/central bank push to collateralize interbank transactions. This may create further tension between the usage of collateral in transactions with the central bank versus other counterparties.

During the financial crisis, the ECB broadened the Eurosystem collateral framework considerably, allowing a broader range of securities of the same credit quality and allowing securities of lower ratings. A strand of the literature addresses the question as to what role the balance sheet of a central bank plays (Hawkins, 2003; Bindseil, Manzanares, and Weller 2004; Caruana, 2011; and Miles and Schanz, 2014) as well as asking whether a central bank can default or impinge its credibility by weakening its balance sheet (Stella, 1997; Ernhagen, Vesterlund, and Viotti, 2002; and Buiter, 2008). The recent revisiting of these questions is a result of a concern in some quarters that central banks could be at risk, at least from being able to implement effective policies. By allowing riskier securities as collateral, the ECB has increased its risk, both in financial and political terms, as emphasized by Klaas Knot.

Collateral also plays a direct role in the secondary market for liquidity, notably in repos, and much research is devoted to this topic. As predicted by Duffie (1996), the evidence shows that collateral that trades special in the repo market also trades at a premium in the cash market (Jordan and Jordan, 1997, and Buraschi and Menini, 2002). Not surprisingly, the risk of the underlying collateral adversely affects the repo rate (Bartolini, Hilton, Sundaresan, and Tonetti, 2011).

Researchers have also asked the question as to whether the collateralization of transactions in the market for liquidity affects financial stability. Intuitively, collateral can be expected to have a stabilizing effect (Ewerhart and Tapking, 2008; Heider and Hoerova, 2009). However, theoretically, collateral can also turn out to be destabilizing (Kiyotaki and Moore, 1997; Brunnermeier and Pedersen, 2009) when it is combined with credit limits and shocks to asset values. Gorton and Metrick (2012) argue that the financial crisis in the US was characterized 
by a run on bilateral repos with securitized assets as collateral. A run in this case means an extreme increase in haircuts. Their main argument is that the underlying securities became more risky and therefore more information sensitive (Gorton and Metrick, 2010). Krishnamurty, Nagel, and Orlov (2014) disagree with this view, arguing instead that the evidence is more consistent with a credit crunch than with a run. However, these authors study different segments of the repo market. Whatever the case, the evidence shows that repo markets were not unaffected by the crisis and may well have played an integral part in it.

The evidence also shows that an increase in market risk is associated with a shift towards safer collateral (Mancini, Ranaldo, and Wrampelmeyer, 2014). Thus, default risk appears to be a consideration in the repo market. Furthermore, a shift towards higher quality collateral in secondary market repos may leave lower quality collateral to be used in repos with the central bank. Safety concerns and regulatory innovations such as the Liquidity Coverage Ratio (BCBS, 2013a) are likely to further increase banks' demand for high quality assets. Thus, the efficient use and potential re-use of collateral emerge as important considerations (Singh and Stella, 2012; CGFS, 2013; Singh, 2013).

Collateral also plays an important role in real transactions (Bernanke and Gertler, 1989 and 1990; Calomiris and Hubbard, 1990; Kiyotaki and Moore, 1997). This literature establishes a link between collateralized borrowing and asset prices and investments. Notably, the net worth of collateral impacts the investment capability of a firm. This is analogous to a repo transaction, where the form of collateral is not an asset or real estate but a security.

While there is a substantial literature on collateral, as sketched above, little of this research looks directly at the design and consequences of a central bank's collateral framework. Nyborg and Strebulaev (2001) show theoretically that allocational inefficiencies in the market for liquidity may depend on the size of the set of eligible collateral, but do not consider collateral heterogeneity, which is a crucial issue handled by collateral frameworks in practice. In another theoretical contribution, Chapman, Chiu, and Molico (2011) show that haircuts in central bank collateral frameworks can influence investment decisions; when haircuts on illiquid assets are "too low," an overinvestment in these may take place, leaving the central bank at risk and reducing welfare. Related to this, Buiter and Sibert (2005) and Ashcraft, Gârleanu, and Pedersen (2010) argue that there may 
be an inverse relation between haircuts in repos with the central bank and the secondary market prices of the underlying collateral. The latter paper provides empirical evidence to back up this theoretical claim.

\section{Collateral Frameworks}

Central bank collateral frameworks are fundamental institutional features of the monetary and financial system that have gone largely unstudied by researchers, perhaps because they are simply taken for granted and seem of little consequence in times of normalcy. They are also often complex and opaque, requiring the studying of numerous legal documents to be accurately understood. Their basic function is to define the set of eligible collateral financial institutions can use in

operations with central banks to obtain central bank money (liquidity). They also determine the quantity of liquidity that a central bank will supply for each eligible collateral, by, for example, setting haircuts in repos with eligible counterparties ("banks"). This places collateral frameworks at the core of the monetary system and the financial system that extends (from) it.

This section provides an overview of the role played by collateral frameworks, with an emphasis on potential biases and distortions that may arise from their design. I sketch out some theoretical issues and use the important case of the Eurosystem's collateral framework to shed light on how that particular framework functions in practice. Further details are provided in Nyborg (2015), which unpacks the legal rules of the Eurosystem's collateral framework and brings to light the practical implications of these rules through a forensic style empirical investigation. The current section reviews some of the key findings of that investigation. A central characteristic of the Eurosystem's collateral framework is its broad eligibility criteria. Thus, the findings summarized in this paper are especially relevant with respect to understanding potential issues that arise in collateral frameworks sharing this characteristic. My general point is that collateral frameworks have potentially far-reaching effects on financial markets and the real economy. They are at the core of the monetary system and, as observed by Bagehot (1873), "[m]oney is economical power." 


\subsection{Potential impact}

There are several dimensions to the potential impact of collateral frameworks. Because eligibility means that a security can be refinanced through, or bought by, the central bank, this can affect its repo rate, liquidity, and price in the secondary market. The haircuts applied by the central bank to different collateral may be set so that the impact of eligibility differs across asset classes and individual securities, possibly by design or even inadvertently.

For instance, in order to make banks' balance sheets more liquid, the central bank can favor especially illiquid collateral by giving these relatively low haircuts. While this may help channel liquidity "where it is needed," a side effect is that it may cause distortions in money and asset markets by reducing the role of market discipline. In addition, an impairment in the efficiency of the market for liquidity can spill over into the broader financial markets as shown by Nyborg and Östberg (2014) and, from there, to the real economy.

Collateral frameworks that favor illiquid collateral may also stimulate the endogenous production of it. In turn, this may lead to a misallocation of funds in the real economy towards assets that are fundamentally less liquid in a real sense, that is, assets that have very long-dated returns in terms of goods and services. $^{8}$

To follow the logic, it is important to understand that central banks control central bank money, that is, nominal balances. If there is a low level of current goods and services, there is little a central bank can do about it in the short run. When we speak of collateral being illiquid, we typically mean this in a nominal sense; selling it may involve accepting a discount in the price and the more so the more one wishes to sell. While a policy of favoring illiquid collateral may serve a useful purpose in some situations, it can also give rise to problems if this collateral is also illiquid in a real sense, as seems plausible. Favoring illiquid collateral in the collateral framework may then lead to an overproduction of illiquid real assets.

\footnotetext{
${ }^{8}$ This relates to Chapman, Chiu, and Molico's (2011) result that low haircuts on illiquid assets may tilt portfolios in that direction and also to the arguments of Buiter and Sibert (2005) and Ashcraft, Gârleanu, and Pedersen (2010) that haircuts affect prices. In turn, these can be seen as special versions of Amihud and Mendelson's (1986) general point that portfolios may be optimally tilted away from illiquid assets by agents that have more immediate liquidity needs. However, these papers do not discuss nominal versus real liquidity or collateral frameworks as such.
} 
Tilting the economy towards an overproduction of illiquid real assets is likely to be inefficient and may exacerbate business cycles. A policy of favoring illiquid collateral in a depressed economy may make it harder for the economy to recover.

Housing, especially second homes, is an example of illiquid real assets. The real returns are long dated. Countries such as Spain and Ireland are still grappling with the aftermath of a prolonged boom in house building. In the case of Spain, much of this was touristic housing, including second-home villas and apartments that stand empty much of the time. Below, I will address whether the collateral framework in the Eurosystem favors illiquid collateral.

The banking literature has raised the issue that banks may be underincentivized to channel funds to assets that are liquid in a real sense because of a free-rider problem among them. In particular, as emphasized by Bhattacharya and Gale (1987), the provisioning of liquidity is a public good. Thus, if liquid investments have lower returns than less liquid ones, banks have an incentive to free-ride on other banks. When each bank relies on other banks to promote liquid, low return investments, the end result is an underprovisioning of "real liquidity" in the system as a whole. ${ }^{9}$ A central bank that attempts to offset the problem of an underprovisioning of real liquidity by providing nominal balances on favorable terms to illiquid real assets does not solve the free-rider problem, but exacerbates it. Thus, a collateral framework that favors illiquid collateral may ultimately promote a misallocation of funds in the real economy because it affects individual banks' incentives seen in isolation, as discussed above, and also enhances the free-rider problem among banks with respect to the private provisioning of liquidity.

Collateral frameworks can also impinge on market discipline and bank's incentives to monitor creditors by accepting collateral that does not trade at all. They can support the influence of politics on banks and the financial system by

\footnotetext{
${ }^{9}$ The distinction between "liquid" and "illiquid" assets in Bhattacharya and Gale's (1987) is based on the timing of returns in terms of goods or services. "Liquid" assets are ones with a relatively low duration. In other words, "liquidity" in their analysis refers to assets that are liquid in a real sense. For the most part, the theoretical banking literature has not considered the real-world distinction between nominal and real assets. Most of the literature is written in terms of real assets, ignoring money and the vital function of banks in the money creation process. Some exceptions are Champ, Smith, and Williamson (1996), Allen and Gale (1998), Diamond and Rajan (2006), Skeie (2008), and Allen, Carletti, and Gale (2014).
} 
extending favorable terms to collateral with local, regional, or central government guarantees. Haircut rules and guarantee policies can interact to increase market segmentation. Collateral framework can facilitate indirect bailouts, propping up poorly performing banks that should optimally be resolved instead.

What a central bank accepts in exchange for central bank money also affects its own balance sheet. Perceived weaknesses in a central bank's balance sheet can ultimately affect agents' trust in it, its money, and even the political body or bodies, that created and support the central bank. Witness the "end the Fed" and "back to gold" movements in the US and the numerous calls to break up the euro. ${ }^{10}$ The threat to the euro has been real enough to lead the ECB to engage in a prolonged battle to save it. Many commentators have expressed the view that a break-up of the euro will also mean a break-up of the European Union. This underscores the importance of sound monetary policies, including sound collateral frameworks.

\subsection{Collateral eligibility and usage in the euro area}

In most currency areas, central bank money is provided to banks against a wide set of eligible collateral with potentially different liquidity and risk characteristics (ECB, 2013; BIS, 2013). The set of eligible collateral in the euro area is especially large. At times, more than 40,000 ISINs have been on the public list of eligible "marketable" collateral, with the number over time being around 30-40,000 ISINs. ${ }^{11}$ The set of eligible collateral ranges from sovereign bonds to unsecured bank bonds and asset backed securities, with a large span of ratings within all asset classes. At the end of 2013, these had a value of around EUR 14 trillion, having grown from approximately EUR 7.7 billion at the end of 2004 (see, e.g., Nyborg, 2015). Banks can also pledge non-marketable assets such as credit claims. Guarantees by governments, corporations, and other entities can be, and are, used to provide eligibility to otherwise non-eligible collateral. "Mar-

\footnotetext{
${ }^{10}$ See, e.g., Paul (2009) and a Bloomberg National Poll in 2010 in which $16 \%$ of the respondents said the Federal Reserve should be abolished (http://www.bloomberg.com/news/201012-09/more-than-half-of-americans-want-fed-reined-in-or-abolished.html), or "House Republicans Resume Efforts to Reduce Fed's Power," by Binyamin Appelbaum, New York Times, July 10, 2014 (http://www.nytimes.com/2014/07/11/business/house-republicans-restart-theirwaron-the-fed.html?).

${ }^{11}$ ISIN is International Securities Identification Number.
} 
ketable" collateral without such guarantees or external ratings can be made privately eligible through the use of approved in-house ratings. The same collateral is eligible across all operations, main and long term refinancing operations and the marginal lending facility (discount window) alike. The Eurosystem therefore offers an ideal setting for gaining insight into collateral frameworks with broad eligibility criteria, in addition to being important in its own right. ${ }^{12}$

\section{Insert Figure 3 here.}

Figure 3 provides evidence on the production and usage of eligible collateral in repos with the Eurosystem from 2004 to 2013. The data underlying the graphs is taken from the ECB's webpage. Over this time period, the outstanding amount of central bank money injected in repos grew from EUR 345.1 to 717.1 billion, having peaked in 2012 at EUR 1.1 trillion. Over the same time, Eurosystem holdings of euro denominated securities issued by euro area entities grew from EUR 70.2 to 586.1 billion. $^{13}$

The ECB provides the data broken down into seven asset classes. These are, from bottom to top in the figure: central government securities, regional government securities, covered bank bonds, corporate bonds, uncovered bank bonds, asset backed securities, and "other marketable assets." As will be seen in Table 1, collateral haircuts in the Eurosystem are increasing in these asset classes in the order just cited. Thus, we can think of them as representing collateral of decreasing "quality" in terms of risk and liquidity, as reflected by haircuts. ${ }^{14}$

The figure contains two graphs, one for nominal values of eligible marketable collateral (3a) and one for usage of marketable and non-marketable assets (3b). The different asset classes are color coordinated, to lump them into three broad categories. The "higher quality" collateral is indicated by blue colors. This is comprised of central and regional government securities. ${ }^{15}$ The "medium quality"

\footnotetext{
${ }^{12}$ The Federal Reserve System also has wide eligibility criteria, but restricts the securities it accepts at its open market operations to Treasury, agency, and agency mortgaged-backed securities (Board of Governors of the Federal Reserve System, 2012; BIS, 2013). For further details on Eurosystem eligibility criteria, see Eberl and Weber (2014) and Nyborg (2015).

${ }^{13}$ This is as tabulated in Nyborg (2015), Table 3, which also provides further details. The original data can be found on the ECB's webpage.

${ }^{14}$ A caveat: it is unclear what securities the category "other marketable assets" represents, although I bundle them with "lower quality" collateral.

${ }^{15}$ Given the sovereign debt crisis in the euro area, it can clearly be argued that not all
} 
collateral is indicated by red colors, this is comprised of covered bank bonds and corporate bonds. Third, the "lower quality" collateral is indicated by green colors and is composed of uncovered bank bonds, asset backed securities, and other marketable assets. When looking at usage, the "green" category of lower quality collateral is augmented by non-marketable assets.

Figure 3 shows that the Eurosystem's collateral framework promotes lower quality collateral. Over time, asset backed securities, uncovered bank bonds, and other "lower quality" marketable assets have become an increasingly larger proportion of the eligible marketable collateral. The increased production of such "low-end" collateral is a logical response to another trend, namely that these collateral classes have become increasingly attractive to use in repos with the Eurosystem, as revealed by the large increase in their usage. From 2004 to 2013, the proportion of these low-end asset classes and non-marketable assets used in repos with the Eurosystem has grown from around 35\% to close to $60 \%$ by value. ${ }^{16}$

That banks use a relatively high proportion of lower quality collateral in Eurosystem liquidity injecting operations might be seen as the natural result of the efficient use of collateral by banks. Nyborg, Bindseil, and Strebulaev (2002) argue that there is heterogeneity in the opportunity costs among the collateral that is eligible to be used in Eurosystem repos which is not eliminated by haircuts. This may arise, for example, as a result of Eurosystem haircuts not reflecting market conditions. Consistent with this view, Nyborg (2015) documents that months and years pass between each time Eurosystem haircuts are updated. That banks use relatively worse collateral in ECB operations suggests that lower quality collateral have relatively low haircuts (adjusted for risk and illiquidity).

Lower quality collateral may also have lower opportunity costs because of their limited use outside of Eurosystem operations. In addition to the approximately EUR 14 trillion (end of 2013) of eligible collateral that is marketable, banks can also use non-marketable collateral, with unknown aggregate value. In comparison, at the end of 2013, the refinancing operations soaked up collateral with a government debt is of high quality. Here, this is not taken into account.

${ }^{16}$ An ECB working paper by Bindseil and Papadia (2006) notes a similar trend in the 1999 to 2005 period as does an IMF working paper by Chailloux, Gray, and McCaughrin (2008) for the 2004 to 2007 period. The latter paper also shows a similar phenomenon occurring in the US with the onset of the financial crisis in the third quarter of 2007. 
collateral value of less than one trillion. Thus, there is a large excess quantity of eligible collateral, some of which is locked out of other markets. For example, the popular Eurex GC Pooling ECB basket contracts include only around 7-8,000 ISINs of the roughly 35,000 ISINs that can be used in Eurosystem repos. ${ }^{17}$

In addition, banks may have a preference for using higher quality collateral in bilateral repos as this saves on default costs. In particular, Ewerhart and Tapking (2008) argue that two-way default risk is an important consideration in bilateral repos. While larger haircuts have the advantage of protecting cash providers against defaults by cash takers (collateral providers), they have the drawback of leading to larger losses to collateral providers in the event that cash providers fail to return the underlying collateral at maturity. This gives rise to a preference for using higher quality collateral in bilateral repos, since such collateral requires lower haircuts to protect the cash provider from cash taker credit risk (assuming default costs are positively related to losses in default). In short, higher quality collateral reduces the total costs of two-way credit risk. The flip side of this is a preference for using lower quality collateral in repos with the central bank. Doing so is possible, of course, only in a system where the central bank does not require the highest quality collateral, as is the case in the euro area.

\subsection{Determinants of collateral values}

Banks' preference for particular types of collateral in repos with the central banks is affected by the terms offered by the central bank. In the euro area, the repo rate is independent of the counterparty and the collateral that is being used. However, haircuts vary across eligible collateral. Haircuts therefore play a key role in the collateral framework.

Haircuts are applied, in principle, to the market value of eligible collateral to yield a collateral's collateral value. The collateral value is the amount that an eligible institution (which I refer to as a bank, for short) can borrow from the central bank with the specified collateral. For a specific eligible collateral $i$ at time $t$, the collateral value, $V_{i, t}^{c}$, is given by

$$
V_{i, t}^{c}=\left(1-h_{i, t}\right) V_{i, t}^{m}
$$

\footnotetext{
${ }^{17}$ See http://www.eurexrepo.com/repo-en/products/gcpooling/. Eurex acts as a central clearing party $(\mathrm{CCP})$ in these contracts.
} 
where $h_{i, t}$ is the haircut and $V_{i, t}^{m}$ is, in principle, the market price of the collateral. I say "in principle" because not all eligible collateral have market prices. Where a market price does not exist or is not sufficiently reliable, the central bank applies the haircut to a theoretical, or model, price instead. Thus, we can think of $V^{m}$ equally as a model or market price.

Questions that naturally arise from these observations include: What are haircuts for different eligible collateral and how are they determined? What determines whether a market or a theoretical price is used? What does a market price actually mean, for example, how recent must it be to count or what kind of volume must it be good for? What fraction of all eligible collateral has a theoretical "market" price for the purpose of calculating collateral values?

Nyborg (2015) addresses these questions and documents, among other things, that around $77 \%$ by count and around $17 \%$ by value, of all eligible collateral have prices that are theoretically determined, rather than taken from the market (estimated, using the official collateral framework pricing rules and Bloomberg as a data source). By way of comparison, banks use well below $10 \%$, by value, of the eligible collateral in repos with the Eurosystem. The percentage of collateral with theoretical prices is higher for lower quality collateral, which may help explain the heavy usage of such collateral, as seen in Figure 3.

Figure 4 unpacks (1) to highlight the elements that determine collateral values in the Eurosystem's collateral framework. Markets affect collateral values directly when a market price of the underlying collateral exists, but non-market factors are also very important.

\section{Insert Figure 4 here.}

First, haircuts are not determined in a market but directly by the ECB. As seen in (1), haircuts have a direct effect on collateral values. They potentially also have an indirect effect because a collateral's haircut in Eurosystem operations may impact on its market value, for example as argued by Ashcraft, Gârleanu, and Pedersen (2010). Nyborg (2015) provides an empirical example that supports this view.

Second, ratings affect every aspect of the collateral value calculation. Haircuts are directly affected by them. Market prices also tend to respond to ratings. They are also likely to be an input to the model used to calculate theoretical prices, 
when that is necessary (but the theoretical models used by the Eurosystem are not publicly available). This gives rating agencies substantial influence. Unfortunately, there is evidence that competition for business among rating agencies often leads to a "race to the bottom," i.e., the rating agency most likely to give the highest rating wins the business (see, e.g., White, 2010, for an overview). But ratings may also be derived from internal models (approved by individual countries' national central banks).

Third, ratings may be affected by guarantees provided to specific collateral or issuers by sovereigns and other players. This opens the door for politics to influence collateral values, since government guarantees may involve politics in some form or another. Guarantees can also influence haircuts directly. Nyborg (2015) provides further details on the role of ratings and guarantees.

In addition to these points, the influence of markets in determining collateral values is reduced by the fact that the ECB accepts a large number of securities that are trading on non-regulated markets as well as non-marketable collateral, for which market prices by definition do not exist. In short, markets play a potentially limited role when it comes to determining collateral values.

\subsection{Euroystem haircuts}

As stated above, Eurosystem haircuts are not drawn from the market, but set by the ECB. Although they reflect risk and liquidity, they do not reflect dayto-day, or even month-to-month, changes in market conditions, because they are so rarely revised. Nyborg (2015) documents that, historically, the average time between revisions is more than three years.

\section{Insert Table 1 here.}

By way of example, Table 1 summarizes the haircut rules for marketable eligible collateral that have been in effect since October 1, 2013. As seen, the ECB's haircut policy (and collateral framework) is built around five liquidity categories, namely: ${ }^{18}$ I. Central government and central bank debt; II. Local and regional government debt, jumbo covered bonds (pfandbrief), agency and supranational debt instruments; III. Traditional pfandbrief and corporate debt;

\footnotetext{
${ }^{18}$ As of October 1, 2013, the ECB refers to the liquidity categories as "haircut categories." Here, I continue to use the older "liquidity category" terminology.
} 
IV. Unsecured bank bonds; and V. Asset-backed securities. For the same residual maturity and coupon policy (zero, fixed, or floating), haircuts are increasing in the liquidity category, with the exception of inverse floaters for which haircuts are the same across liquidity categories. The table also shows that there are two rating categories for eligible collateral, namely, above $\mathrm{A}$ - and $\mathrm{BBB}$ - to $\mathrm{BBB}+$ (on the S\&P scale), with the lower rating category resulting in a higher haircut. ${ }^{19}$ The haircut policy of the ECB can be summarized as follows:

\section{ECB haircut policy: General features}

1. Haircuts are rarely revised over time. Thus, they do not depend on market conditions at particular points in time.

2. Haircuts increase in asset class illiquidity, as measured by the liquidity category.

3. Haircuts increase in risk, as captured by the duration. ${ }^{20}$

4. Haircuts increase in risk, as captured by the rating. There are two rating categories. ${ }^{21}$

5. Within asset classes (liquidity categories), controlling for duration and the two rating categories, there is little differentiation in haircuts between different eligible collateral.

6. Haircuts do not depend on the counterparty. ${ }^{22}$

While the liquidity categories are intended to reflect different liquidity levels, they might also reflect different risk levels. For example, the least liquid category, asset backed securities (V), arguably consists of riskier securities than the most liquid group (I), central government bonds and central bank debt instruments.

\footnotetext{
${ }^{19}$ Nyborg (2015) provides further details on the haircuts on non-marketable collateral, which tend to be larger than those of marketable collateral.

${ }^{20}$ Specifically, they increase in the residual maturity of the collateral and are higher for zero coupon bonds than comparable bonds with fixed coupons.

${ }^{21}$ Prior to October 25, 2008, eligible collateral needed a rating of at least A-, (on the S\&P scale).

${ }^{22}$ There is one exception to this, namely the additional haircuts introduced as of October 1, 2013 for "own-use" collateral. "Own use" refers to collateral issued by a counterparty with which the bank that uses it has "close links." Details on this are provided by Nyborg (2015).
} 
For example, as noted by Calomiris (2009), ratings across asset classes are not comparable with respect to default probabilities. ${ }^{23}$ Of course, developments in the euro area have shown that, in many cases, risk and illiquidity can be substantial for central government bonds as well.

The low level of market input in determining haircuts and the large number of collateral without market prices can help explain why preferences for using particular asset classes arise and how this can persist and even strengthen over time.

Although Eurosystem haircuts are not much affected by the markets, the reverse is not true. Haircuts in the secondary repo market are often taken directly from the Eurosystem's collateral framework. In Nyborg (2015), I examine Eurex' important GC Pooling contracts. These repos are based on a subset of the eligible collateral in Eurosystem operations. According to Eurex officials, they set the haircuts in this contract based on those of the Eurosystem, but may increase them for particular collateral that is perceived to be especially risky. I find that Eurex uses the same haircuts as the ECB in around $93 \%$ of cases. This is a simple piece of evidence that shows that the Eurosystem's collateral framework affects markets.

\subsection{Ratings, guarantees, and further issues}

In Nyborg (2015), I use official European Union/ECB documentation on the Eurosystem's collateral framework to provide a comprehensive summary of haircuts over time, including the haircuts of different types of non-marketable collateral. The role of ratings and guarantees in determining eligibility and haircuts is also examined in detail. The rules give rise to a set of natural questions that are examined through various pieces of data in what can be characterized as a forensic style analysis.

Issues that are examined include the distribution of eligible collateral and their ratings across different asset classes, the relation between primary market and secondary market haircuts, the impact of haircuts on secondary market yields, cross-collateral haircut inconsistencies, the role of rating agencies, the usage and

${ }^{23}$ Calomiris reports that according to Moody's, in 2005 five year default probabilities were 10 times larger for Baa rated CDOs than for Baa rated corporate bonds, the numbers being $20 \%$ and $2 \%$, respectively. 
timing of government guarantees, and the incidence of eligible "marketable" collateral without market prices. The broad-theme conclusions that emerge are that the collateral framework of the Eurosystem is biased towards low quality collateral, does not actively use markets but instead impinges on market discipline, and, in conjunction with the full allotment policy, has been used to facilitate indirect bailouts over the course of the crisis. Some of the more specific findings are as follows.

First, by way of background: as of October 2008, eligible collateral is put into two ratings categories, (i) A- or higher (using Standard \& Poor's scale), and (ii) $\mathrm{BBB}+$ to $\mathrm{BBB}-$, with haircuts in the lower category being higher. The vast majority (around $85 \%$ by count, $90 \%$ by value) of eligible collateral is rated Aor higher, thus receiving the lower haircuts.

Second, by way of background: Until 2009, the accepted external rating agencies were Standard \& Poor's (S\&P), Fitch, and Moody's. In 2009, Dominion Bond Rating Services (DBRS) was added to that list. Only the highest rating counts in Eurosystem operations. I document that DBRS has been pivotal in providing an A- rating for Italy, Ireland, and Spain, and a BBB- rating for Portugal. I estimate that the lower haircuts on government bond from these countries as a result of the pivotal ratings by DBRS is worth around EUR 200-300 billion in increased collateral value. This is especially notable as it is under the full allotment policy, meaning that the full increase in collateral value is available as funding from the Eurosystem. This underscores the important role of DBRS in the Eurosystem's indirect bailout of the weaker sovereigns.

Third, government guarantees are widely used, with the majority of credit institutions with such guarantees being Italian. The usage of government guarantees is unfortunate as it strengthens the nexus between governments and banks and may contribute to market fragmentation. The total value of the guaranteed collateral (from the Italian government to Italian credit institutions) amounts to more than EUR 80 billion and the marginal effect is to increase their total collateral value by around EUR 30 billion. Approximately $50 \%$ of this is due to the A- rating given to Italy by DBRS.

Figure 5 traces out the number of Italian and non-Italian credit institutions with government guaranteed eligible collateral (on the public list). The vertical dotted lines mark the dates of the two three-year LTROs that, as discussed in 
Section 2, provided a total of 1.1 trillion in funding to banks.

\section{Insert Figure 5 here.}

Figure 5 illustrates four points. (i) The number of Italian credit institutions with government guarantees increased rapidly from close to zero to more than 250 over a few days prior to the second three-year LTRO. (ii) The number of Italian credit institutions with government guarantees remained stable until spring/early summer of 2014, when it fell to just below 200. This is still a large number. (iii) The number of non-Italian credit institutions with government guaranteed eligible collateral has decreased steadily from before the first three-year LTRO to the spring of 2014. (iv) Since shortly before the second three-year LTRO, there have been substantially more Italian credit institutions with government guarantees than non-Italian ones. This speaks to a severe worsening of the credit worthiness of the banking sector in Italy over the period covered here. It suggests that the three-year LTROs, and the indirect bailout these represented, were especially important for the Italian banking sector.

Fourth, in the run-up to the second three-year LTRO, the ECB weakened collateral eligibility criteria by admitting 10,516 securities trading on non-regulated markets to the public list of eligible collateral. This increased the number of French and Italian eligible collateral by $198.5 \%$ and $70.8 \%$, respectively. Practically all of this newly admitted collateral were unsecured bank bonds. Spanish, Italian, and French banks had by far the largest uptake in the three-year LTROs, in that order.

Fifth, the announcement on September 4, 2014 that the ECB would purchase asset backed securities and covered bonds, with an aggregate size that was believed at the time to be around EUR 1 trillion, was accompanied by abnormally large stock returns in the euro area. But these were not spread equally across countries. The largest stock returns were seen in the same countries that have benefited from high ratings from DBRS - Portugal, Italy, Ireland, and Spain - as well as Greece. These countries' bank stocks reacted especially positively. The event study findings are consistent with the purchase program being a part of an indirect bailout especially targeting the financially weaker sovereigns and their banks. Nyborg (2015) discusses at length the hypothesis that the ECB's unconventional monetary policies over the course of the crisis have served this role. 


\section{Market Discipline}

Market forces and discipline are important notions in the context of collateral frameworks for several reasons. As illustrated by equation (1) and Figure 4, collateral values are determined by applying haircuts to, in principle, market prices. Furthermore, market discipline is typically viewed as an important complement to financial regulation. It is one of the three pillars in both the Basel II and III bank regulation frameworks (BCBS, 2011). The idea is that banks, like other enterprises, should be regulated not only through formal regulatory rules, but through the competitive forces of the market. More generally, market and competitive forces are central to the efficient allocation of capital and resources. We would expect this principle to be relevant also in the case of the market for liquidity.

An issue raised in this article, however, is that markets are utilized to a relatively small degree by the Eurosystem's collateral framework. Indeed, it appears that many features of the framework are designed to circumvent market discipline. Nyborg (2015) and the findings reviewed in Section 3 offer much by way of detail that speaks to this. The current section distills these findings and discusses some of the consequences of the relative lack of market discipline allowed for by the Euroystem's collateral framework.

\subsection{Market discipline impairment}

Several features of the Eurosystem's collateral framework impinge on market discipline.

First, non-marketable assets are included in the set of eligible collateral. Thus, banks can obtain liquidity without having themselves or their assets assessed in the market. The evidence shows that the usage of non-marketable collateral has increased in the euro area over time, reaching approximately 10\% in 2007 and more than $20 \%$ in 2011 where it has remained (Figure 3).

Second, a substantial fraction of marketable collateral on the public list of eligible collateral trades on non-regulated markets. The evidence shows that the incidence of theoretical prices is much higher for collateral trading on nonregulated markets than for other collateral.

Third, around $77 \%$, by count, of the close to 35,000 ISINs on the public list of 
eligible collateral do not have market prices. By value, the fraction with missing market prices is around $17 \%{ }^{24}$ These estimates come from feeding all ISINs on the public list of eligible collateral on selected dates into Bloomberg. This platform is perhaps the most important source of current market data in the financial industry. The large incidence of collateral on the public list without market prices in Bloomberg is strong support for the thesis that market forces and discipline are not central pillars of the Eurosystem's collateral framework.

Fourth, stale market prices are also a part of the collateral framework for the purpose of determining collateral values. In particular, market prices can be up to five days old. Collateral without a price movement over five days have their prices and therefore collateral values determined theoretically.

Fifth, with respect to determining market prices of eligible collateral, there is no official rule that addresses depth, that is, the volume observed prices are good for. This opens up the possibility of manipulating the prices of thinly traded eligible collateral. This can also affect theoretical prices, since these must necessarily be based on prices of comparable securities. The lack of market depth is especially a concern for illiquid collateral that, by definition, have low volumes.

Sixth, in Eurosystem operations, a bank is allowed to use collateral issued by an entity with which it has close links. The rules with respect to such "own-use" have become increasingly lenient over the course of the crisis.

Seventh, Eurosystem haircuts are set by the ECB rather than determined in the market. Indeed, influence appears to flow in the reverse direction, with the fixed haircuts set by the ECB being adopted by some segments of the market. Nyborg (2015) also provides an example that Eurosystem haircuts influence market prices of eligible collateral, with larger haircuts reducing prices, ceteris paribus.

Eighth, revisions to Eurosystem haircuts are rare. The average time between new overall haircut rules is more than three years, but some classes of collateral have not had their haircuts changed over the almost eleven year period, March 2014 to January 2015.

Ninth, the only market, or near-market, based information that affects haircuts is ratings by external rating agencies (since October 2008). However, there

\footnotetext{
${ }^{24}$ This may be an underestimate because many ISINs have an outstanding value of zero in the Bloomberg system.
} 
is no aggregation of ratings by different agencies. Instead, except for ABSs, only the highest rating matters ("highest-rating rule"), which invites ratings shopping and catering. ${ }^{25}$

There are four accepted rating agencies, S\&P, Fitch, Moody's, and DBRS. The inclusion of DBRS to this list in 2009 has contributed to higher ratings. A purely statistical effect is that the distribution of the highest rating shifts to the right as one adds agencies (unless rating agencies become more conservative as one adds competitors to their business). In addition, as evidenced from sovereign ratings, DBRS also gives higher ratings than the other agencies. It has been pivotal in giving Italy, Spain, and Ireland A- ratings and Portugal a BBB- rating over several years. No other agency has been pivotal for a country rated by DBRS.

Tenth, there are only two ratings categories for the purpose of setting haircuts for eligible collateral, above $\mathrm{A}$ - and $\mathrm{BBB}+$ to BBB-. The ineffectiveness of ratings as a tool by which to differentiate haircuts can be seen from the finding that the vast majority of marketable eligible collateral on the public list are rated A- or higher, the percentage being approximately $85 \%$ by count and $90 \%$ by value. This is surprising, but may be the result of the highest-rating rule.

Eleventh, collateral with ratings below BBB- are in principle not eligible, but exemptions from this rule for sovereign bonds with lower ratings are standard. ${ }^{26}$

Twelfth, while a rating from an approved external rating agency, either for the issue, the issuer, or the guarantor, is necessary to be on the public list, collateral can also be made eligible privately through the use of a national central bank (NCB) or approved in-house or third party rating. It is not clear how much such "privately eligible" collateral exists or is used, but one could venture a guess that the "other marketable collateral" category in Figure 3 represents such collateral. Figure 3 shows that this category has increased over the course of the crisis, but was also used in the pre-crisis years. The collateral framework recognizes that banks have an incentive to shop around for the most favorable model or tweak their own model, by not allowing banks to use more than one model per year (ECB, 2006/12). This is implicit recognition that private ratings models pose a

\footnotetext{
${ }^{25}$ For ABSs, the most recent rule is that the second highest rating is what matters.

${ }^{26}$ Greece and Cyprus have received exemptions. No other euro area country has been rated below BBB-. However, the lowering of the ratings floor to BBB- took place as sovereign ratings started to come under pressure following Lehman's bankruptcy.
} 
potential problem. Given the abundance of eligible collateral on the public list, it is an open question as to why privately eligible collateral is allowed.

Thirteenth, guarantees can be used to boost ratings. This reduces the role of markets and potentially enhances the role of politics. Government guarantees increased greatly in advance of the second three-year LTRO in February 2012, especially in Italy (Figure 5). The run up to this LTRO also saw the inclusion of more than 10,000 securities trading on non-regulated markets into the set of eligible collateral.

The full allotment policy introduced in October 2008 enhances these potential sources of market discipline impairment. This is so because, under this policy, banks can obtain all the liquidity and funding they wish directly from the central bank. Banks are only constrained by the value of their collateral within the Eurosystem, as determined by equation (1). The quantity of central bank money has increased substantially after the introduction of the full allotment policy, thus placing more demands on collateral and magnifying the distortions that arise from the impairment of market forces.

\subsection{Biases and systemic arbitrage}

As discussed in above, the collateral framework in the euro area is biased towards what we can think of as lower quality collateral. There appears to be a preference, or bias, towards the usage of more illiquid and risky collateral that has increased over time. The production of lower quality collateral has increased as well.

These findings are consistent with the anecdotal evidence that there is a pecking order for the use of collateral as follows:

- Lowest quality collateral used with central bank.

- Intermediate quality collateral used in CCP repos.

- Best quality collateral used in bilateral repos.

This pecking order must reflect the efficient use of collateral by banks. That the lowest quality collateral is used in repos with the Eurosystem may, in part, result from CCPs not accepting the very worst collateral and, in part, that two-sided credit risk in bilateral repos tend to favor higher quality collateral, as discussed in Section 3. But it is also likely a reflection of collateral values in Eurosystem 
repos being relatively high for low quality collateral, since banks have an incentive to use collateral in repos with the central bank that is valued relatively highly within the collateral framework as compared to in the markets.

We can say that the collateral framework provides the banks with an opportunity for engaging in collateral arbitrage vis-à-vis the central bank. Banks can use the worst quality collateral in repos with the Eurosystem to obtain central bank money and then turn around and reallocate that liquidity amongst themselves, saving on the best quality collateral in the process. This can also be thought of as a form of systemic arbitrage by the banks in aggregate, since they are essentially arbitraging the monetary system. Empirical support for this view is provided by Fecht, Nyborg, Rocholl, and Woschitz (2015), using detailed bank-level data.

Equation (1) shows that relatively high collateral values of low quality collateral can result from relatively small haircuts or relatively large prices. Haircuts are under the control of the central bank. For the most illiquid collateral, prices are also ultimately controlled by the central bank since such collateral has its price determined theoretically. Hence, the more illiquid the collateral, the bigger is the role of the central bank in setting the collateral value. Given the preference for using illiquid collateral in repos with the Eurosystem, this suggests that the Eurosystem is especially generous when it comes to illiquid collateral.

Such central bank generosity may well be the result of a deliberate intent to "channel liquidity where it is needed." The preference can get stronger over time, as the evidence suggests is the case, if the gap in liquidity between more liquid and less liquid collateral increases. This is so because haircuts are stale and, more generally, because haircuts and collateral values do not respond much to market forces, as discussed above. These features of the collateral framework also mean that the bias can increase over time through banks' (endogenously) creating illiquid collateral to take advantage of the good terms on such collateral on offer in Eurosystem repos. This is especially a concern under the full allotment policy. It is also important to note that a direct corollary of a central bank policy to directly "channel liquidity where it is needed" is that interbank trade, and thereby market discipline, is undermined. 


\subsection{Potential costs}

The undermining of market discipline in the market for liquidity means that market signals are obscured, thus making supervisors' and regulators' job harder. The bias towards lower quality collateral that the Eurosystem's collateral framework appears to promote has several additional implications. These issues are of increasing importance as the volume of central bank repos grows under the full allotment policy.

For example, as discussed in Section 3, favoring illiquid collateral in central bank repos may stimulate the production of such collateral and distort investments in the real economy away from assets that are liquid in a real sense. A contributing factor to such distortions is the free-rider problem inherent in the private provision of liquidity (Bhattacharya and Gale, 1987). A collateral framework that is biased in favor of illiquid financial assets can exacerbate this freerider problem, especially if these assets are also illiquid in a real sense, as seems plausible. In other words, favoring illiquid financial assets through the collateral framework can lead to suboptimal investment decisions and intertemporal consumption patterns. In more plain language, it can contribute to an amplification of business cycles.

In addition, promoting illiquid collateral through the collateral framework can also make the banking, and financial, system more vulnerable to liquidity shocks. Several authors have suggested that the breakdown in the interbank market during the financial crisis was related to increased levels of information asymmetry among banks with respect to the quality of their balance sheets (see, e.g., Heider, Hoerova, and Holthausen, 2009). A collateral framework that is biased towards more illiquid collateral can make such a systemic crisis more likely.

The promotion of lower quality collateral also weakens the balance sheet of the central bank. This can make the central bank less able to respond to problems in the banking system and, in extreme scenarios, undermine its credibility. One typically thinks of the soundness of the central bank as being important for the well functioning of the financial system. For example, Stella (1997, p. 33) concludes that a weak and deteriorating central bank balance sheet is likely to lead to price instability or financial repression. Stella (2005) also emphasizes the importance of the strength of the balance sheet to maintain central bank 
independence and thus support the credibility of its policies (see also Sims, 2004, and Jeanne and Svensson, 2007). In the euro area, it is hard to predict the outcome of the turmoil that is likely to ensue should the ECB or one of the national central banks need recapitalization.

As noted in Section 2, central bankers such as Thomas Jordan and Klaas Knot, among others, have also expressed concern about increasingly weak central bank balance sheets over the course of the crisis. Klaas Knot goes as far as saying that weak balance sheets can "...undermine a central bank's credibility..." and that "...central banks may need to step up their efforts on transparency and accountability" (Knot, 2013). Given this view, it is notable that the Eurosystem's collateral framework promotes risky and illiquid collateral.

A weak central bank can also affect economic activity negatively because economic agents start to lose faith in the central bank's money and the financial system it supports. As suggested by Nyborg (2011), we can think of the assets of a central bank as representing the "gold" that backs up the money. Reductions in the value or liquidity of those assets, like the debasement of gold coins, can result in reduced faith in the central bank's money. In turn, this can lead to a lower willingness to trade and invest. The recent crisis can be seen as an example of this, with the price of gold and other commodities skyrocketing while the economy went into deep recession.

A final important feature of the collateral framework in the euro area that has the potential to create distortions is that haircuts are independent of the counterparty. Individual banks' credit risk is not taken into account. Such a policy may well be justified as "levelling the playing field" by providing access to liquidity at similar terms (but against heterogeneous collateral). It could also be justified on logistical grounds, given that there are 30-40,000 eligible ISINs and thousands of banks. However, a counterparty-independent haircut policy also creates the potential for distortions because it provides incentives for a bank to submit collateral whose default probability is highly correlated with a default of the bank itself (Fecht, Nyborg, Rocholl, and Woschitz, 2015). This may well be the largest concern for the central bank with respect to its own solidity.

The incentive created by the collateral framework to use highly correlated collateral may have contributed to the increasing level of segmentation across 
countries in the euro area. ${ }^{27}$ Probabilities of sovereign defaults increased significantly over the crisis, as evidenced by the sovereign debt crisis (and the accompanying increase in yield spreads between Germany and other sovereigns), and the solvency of a bank in a particular country is more closely linked to the solvency of that country than that of another country. The increasing use of guarantees from governments to credit institutions in the same country tightens this bond. Government guarantees thereby also contribute to segmentation.

Fragmented markets are unattractive as they are a hindrance to the free flow of capital. That fragmentation may also represent increased bank default probabilities is an additional cause for concern. Worries about market fragmentation were an important driver behind the push for a European Banking Union. As observed by Benoit Cœuré, member of the executive board of the ECB, in the context of the establishment of the European Banking Union "The negative feedback loop between banks and sovereigns as well as signs of market fragmentation made European leaders take an extraordinary decision last summer, namely to establish the European Banking Union." (Cœuré, 2013).

To summarize, there are numerous features of the Eurosystem's collateral framework that impair market discipline. The more market forces are neutralized, the more likely it is that the committees that decide on haircuts and theoretical "market prices" get it wrong, leading in the first instance to financial market distortions as well as influencing bank behavior.

The evidence suggests that the collateral framework is biased towards lower quality collateral. This affects the balance sheet of the Eurosystem. It also affects banks because the collateral framework provides a set of incentive constraints with respect to the behavior of banks and bankers. In turn this must necessarily affect the real economy, since the money creation process is intimately linked to the channeling of funds to the real economy. Because these biases were present pre-crisis, it may well be that they have been a contributing factor to the prolonged problems in the euro area. An important question that is raised by the discussion in this section is to what extent it is desirable to design and use collateral frameworks to favor certain assets or institutions or encourage particular behavior.

\footnotetext{
${ }^{27}$ For evidence on fragmentation in the euro area, see, for example, ECB (2012), ECB (2014), van Rixtel and Gasperini (2013), Al-Eyd and Berkmen (2013), and Acharya and Steffen (2015).
} 


\section{Concluding remarks}

Well functioning monetary and financial systems are important to the efficient flow of resources and private and social welfare. This point has been brought home emphatically by the global financial crisis and accompanying recession that emerged in August 2007 and that has taken years to resolve. As late as January 2015, the ECB was still heavily engaged in its fight to preserve the euro. Numerous proposals have been advanced regarding how to "fix" the monetary and financial systems and regulate banks and other types of monetary and financial enterprises. Widespread financial market interventions by central banks have made it difficult to gauge "correct" market prices and, in private, even many central bankers express this exact view. This undermines the efficient allocation of resources in the economy. Improving our understanding of the workings of the monetary and financial system is therefore of central and, also urgent, importance.

The broad perspective put forth in this article and in Nyborg (2015) is that monetary and financial systems are fundamentally built on top of the collateral that central banks choose to accept in exchange for central bank money. To understand money and the broader financial system, it is therefore necessary to understand central bank collateral frameworks.

I have taken a first step in that direction by discussing how collateral frameworks work and interact with markets, banks, and, ultimately, the real economy. I argue that collateral frameworks can bias the private provision of real liquidity and thereby also the allocation of resources in the economy. They can affect market prices of financial assets and undermine the efficient working of money markets. More generally, they can impair market forces and discipline and promote politics in the monetary and financial system. Most obviously, collateral frameworks affect the balance sheets of central banks. As emphasized by Klaas Knot, President of the Dutch central bank, a weak balance sheet can undermine a central bank's credibility, with unfortunate consequences for financial stability and the real economy. These issues have been explored using the very interesting and intriguing case of the euro area as a basis of illustration and case study.

The collateral framework designed by the ECB for the euro appears to suffer, to varying degrees, from all of the above predicaments. Most striking, perhaps, is 
how it appears to sidestep market discipline. The amount of central bank money a bank can obtain from the Eurosystem against a given security, the security's collateral value, is set by the ECB with relatively minor input from the markets. Haircuts do not reflect market conditions and the prices to which they are applied to calculate collateral values are in the majority of cases based on theoretical models rather than direct market prices. Given that there are 30-40,000 different securities on the public list of eligible collateral in the Eurosystem, the lack of market forces in setting the terms of exchange between banks and the Eurosystem is, perhaps, not surprising.

That the ECB sets collateral values with little market input points to the collateral framework being a tool of the central bank. This is especially so because the terms of exchange spill over into other markets. We know, for example, that Eurosystem haircuts are used in repos organized by central counterparties. Incentives to produce collateral are affected too. There has been a growth in the production and usage of lower quality collateral over time. This leads to the question as to why the ECB should wish to promote lower quality collateral. More generally, what is the ECB targeting with its collateral policy and why is market discipline more or less undermined by the collateral framework? Why does its collateral framework allow for the various "oddities" documented and reviewed in this article and further in Nyborg (2015)? As explained by, for example, Bindseil and Papadia (2006) and Bindseil (2014), one of the considerations the ECB has in mind with respect to its collateral policies is its own risk management. What is less clear is why this should involve such a small role for market forces.

Given the role of politics in so many other spheres that relate to the euro, ${ }^{28} \mathrm{a}$ plausible explanation is that market discipline is de-emphasized to accommodate the different countries that comprise the euro area. This may serve the function to ease the constraints imposed by having a single currency for disparate economies. It may reflect a wish to channel liquidity "where it is needed," although this should really be a job for the secondary market for liquidity rather than the primary market. Any such need on economic grounds must relate to a lack of integration of euro area money markets. Whatever the case, the lack of a role for market forces in the collateral framework leaves rooms for politics as a source of influence over this central element of monetary policy. Politics can affect the

\footnotetext{
${ }^{28}$ See, e.g., Nyborg (2015).
} 
set of eligible collateral as well as collateral values. As documented in this paper, government guarantees are used to gain eligibility and improve collateral values.

While issues relating to the euro necessarily have occupied a large part of this paper, its main message is that collateral frameworks are an important part of monetary policy. Because their influence reaches to financial markets and the real economy, more knowledge and transparency about collateral frameworks would be welcome so that economists can start to gauge their impact and, hopefully, even better monetary policies can be pursued. 


\section{References}

Abbassi, Puriya, Falk Bräuning, Falko Fecht, and Jóse-Luis Peydró, 2014, Crossborder liquidity, relationships and monetary policy: Evidence from the euro area interbank crisis, Discussion paper 45, Deutsche Bundesbank.

Acharya, Viral V. and Sascha Steffen, 2015, The "greatest" carry trade ever? Understanding eurozone bank risks, Journal of Financial Economics, 115, 215236.

Afonso, Gara, Anna Kovner, and Antoinette Schoar, 2011, Stressed, not frozen: The federal funds market in the financial crisis, Journal of Finance, 66, 11091139 .

Al-Eyd, Ali and S. Pelin Berkmen, 2013, Fragmentation and monetary policy in the euro area, IMF Working paper 208.

Allen, Franklin, Elena Carletti, and Douglas Gale, 2014, Money, financial stability and efficiency, Journal of Economic Theory, 149, 100-127.

Allen, Franklin and Douglas Gale, 1998, Optimal financial crises, Journal of Finance, 53, 1245-1284.

Amihud, Yakov and Haim Mendelson, 1986, Asset pricing and the bid-ask spread, Journal of Financial Economics, 17, 223-249.

Angelini, Paolo, 2008, Liquidity and announcement effects in the euro area, Giornale degli Economisti e Annali di Economia, 67, 1-20.

Ashcraft, Adam, Nicolae Gârleanu, and Lasse H. Pedersen, 2010, Two monetary tools: Interest rates and haircuts, NBER Macroeconomics Annual 2010, 25, 143180 .

Bagehot, Walter, 1873, Lombard street: A description of the money market, Richard D. Irwin, Inc., Homewood, Illinois, 1962, reprinted from the Scribner, Armstrong \& Co., edition, New York, 1873.

Bartolini, Leonardo, Spence Hilton, Suresh Sundaresan, and Christopher Tonetti, 2011, Collateral values by asset class: Evidence from primary securities dealers, Review of Financial Studies, 24, 248-278.

BCBS (Basel Committee on Banking Supervision), 2011, Basel III: A global regulatory framework for more resilient banks and banking systems, Bank for International Settlements, June, ISBN 92-9197-859-0 (online).

BCBS, 2013a, Basel III: The liquidity coverage ratio and liquidity risk monitoring tools, January, ISBN 92-9197- 912-0 (online). 
BCBS, 2013b, Central bank collateral frameworks and practices, March, ISBN 92-9197-926-0 (online).

Beirne, John, 2012, The EONIA spread before and during the crisis of 20072009: The role of liquidity and credit risk, Journal of International Money and Finance, 31, 534-551.

Bernanke, Ben S. and Mark Gertler, 1989, Agency costs, net worth, and business fluctuations, American Economic Review, 79, 14-31.

Bernanke, Ben S. and Mark Gertler, 1990, Financial fragility and economic performance, Quarterly Journal of Economics, 105, 87-114.

Bernanke, Ben S. and Kenneth N. Kuttner, 2005, What explains the stock market's reaction to federal reserve policy, Journal of Finance, 60, 1221-1257.

Bhattacharya, Sudipto and Douglas Gale, 1987, Preference shocks, liquidity and central bank policy, New Approaches to Monetary Economics, Chapter 4, 69-88, W. Barnett, and K. Singleton, eds., Cambridge University Press, Cambridge.

Bindseil, Ulrich, 2014, Monetary policy operations and the financial system, Oxford University Press, Oxford.

Bindseil, Ulrich, Andrés Manzanares, and Benedict Weller, 2004, The role of central bank capital revisited, Working paper 392, European Central Bank.

Bindseil, Ulrich, Kjell G. Nyborg, and Ilya A. Strebulaev, 2009, Repo auctions and the market for liquidity, Journal of Money, Credit and Banking, 41, 13911421.

Bindseil, Ulrich and Francesco Papadia, 2006, Credit risk mitigation in central bank operations and its effects on financial markets: The case of the Eurosystem, Occasional paper 49, European Central Bank.

BIS (Bank for International Settlements), 2013, Central bank collateral frameworks and practices, A report by a study group established by the markets committee, March, ISBN 92-9197-926-0 (online).

Board of Governors of the Federal Reserve System (July, 2012), "Collateral and rate setting," Monetary Policy - Credit and Liquidity Programs and the Balance Sheet found on July 8, 2014 under http://www.federalreserve.gov/ monetarypolicy/bst_ratesetting.htm.

Brunnermeier, Markus K. and Lasse H. Pedersen, 2009, Market liquidity and funding liquidity, Review of Financial Studies, 22, 2201-2238.

Buiter, Willem H., 2008, Can central banks go broke?, CEPR Discussion paper 
6827.

Buiter, Willem H. and Anne C. Sibert, 2005, How the Eurosystem's treatment of collateral in its Open Market Operations weakens fiscal discipline in the eurozone (and what to do about it), CEPR Discussion papers 5387.

Buraschi, Andrea and Davide Menini, 2002, Liquidity risk and specialness, Journal of Financial Economics, 64, 243-284.

Calomiris, Charles W., 2009, A recipe for ratings reform, The Economists' Voice, 6.

Calomiris, Charles W. and R. Glenn Hubbard, 1990, Firm heterogeneity, internal finance, and 'credit rationing', Economic Journal, 100, 90-104.

Carpenter, Seth and Selva Demiralp, 2006, The liquidity effect in the federal funds market: Evidence from daily open market operations, Journal of Money, Credit and Banking, 38, 901-920.

Caruana, Jaime, 2011, Why central bank balance sheets matter, Keynote address at the Bank of Thailand, BIS conference.

Cassola, Nuno, Cornelia Holthausen, and Marco Lo Duca, 2010, The 2007/2009 turmoil: A challenge for the integration of the euro area money market?, Working paper, European Central Bank.

CGFS (Committee on the Global Financial System), 2013, Asset encumbrance, financial reform and the demand for collateral assets, CGFS Papers 49, May, ISBN 92-9197-935-X (online).

Chailloux, Alexandre, Simon Gray, and Rebecca McCaughrin, 2008, Central bank collateral frameworks: Principles and policies, Working paper 222, International Monetary Fund.

Champ, Bruce, Bruce D. Smith, and Stephen D. Williamson, 1996, Current elasticity and banking panics: Theory and evidence, Canadian Journal of Economics, $29,828-864$.

Chapman, James T.E., Jonathan Chiu, and Miguel Molico, 2011, Central bank haircut policy, Annals of Finance, 7, 319-348.

Cheun, Samuel, Isabel von Köppen-Mertes, and Benedict Weller, 2009, The collateral frameworks of the Eurosystem, the Federal Reserve System and the Bank of England and the financial turmoil, Occasional Paper 107, European Central Bank.

Chordia, Tarun, Asani Sarkar, and Avanidhar Subrahmanyam, 2005, An empiri- 
cal analysis of stocks and bond market liquidity, Review of Financial Studies, 18, 85-130.

Cœuré, Benoit, The single resolution mechanism: Why it is needed, 2013, Speech at the ICMA Annual General Meeting and Conference, organized by the International Capital Market Association, Copenhagen, May 23.

Diamond, Douglas W. and Raghuram G. Rajan, 2006, Money in a theory of banking, American Economic Review, 96, 30-53.

Duffie, Darrell, 1996, Special repo rates, Journal of Finance, 51, 493-526.

Eberl, Jakob and Christopher Weber, 2014, ECB collateral criteria: A narrative database 2001-2013, Ifo Working Paper.

ECB (European Central Bank), 2012, Indicators of market segmentation: Media request following the ECB press conference on 2 August 2012, https://www. ecb.europa.eu/pub/pdf/other/is120802_media_request.en.pdf.

ECB, 2013, Collateral eligibility requirements: A comparative study across specific frameworks, July, ISBN 978-92-899-1014-9 (online).

ECB, 2014, Annual report 2013, ISSN 1725-2865 (online).

ECB (2000/7), "GUIDELINE OF THE EUROPEAN CENTRAL BANK of 31 August 2000 on monetary policy instruments and procedures of the Eurosystem," Official Journal of the European Communities L 310, General framework, 11.12.2000, pp. 1-2 \& 31-44.

ECB (2006/12), "GUIDELINE OF THE EUROPEAN CENTRAL BANK of 31 August 2006 amending Guideline ECB/2000/7 on monetary policy instruments and procedures of the Eurosystem," Official Journal of the European Union L 352, General framework, 13.12.2006, pp. 1-2 \& 35-56.

ECB (2011/4), "DECISION OF THE EUROPEAN CENTRAL BANK of 31 March 2011 on temporary measures relating to the eligibility of marketable debt instruments issued or guaranteed by the Irish Government," Official Journal of the European Union L 94, Temporary framework, 8.4.2011, pp. 33-34.

ECB (2013/35), "DECISION OF THE EUROPEAN CENTRAL BANK of 26 September 2013 on additional measures relating to Eurosystem refinancing operations and eligibility of collateral," Official Journal of the European Union L 301, General framework, 12.11.2013, pp. 6-12.

ECB (2013/36), "DECISION OF THE EUROPEAN CENTRAL BANK of 26 September 2013 on additional temporary measures relating to Eurosystem refinancing operations and eligibility of collateral," Official Journal of the European 
Union L 301, Temporary framework, 12.11.2013, pp. 13-14.

Ernhagen, Tomas, Magnus Vesterlund, and Staffan Viotti, 2002, How much equity does a central bank need, Sveriges Riksbank Economic Review, 2, 5-17.

Ewerhart, Christian and Jens Tapking, 2008, Repo markets, counterparty risk and the 2007/2008 crisis, Working paper 909, European Central Bank.

Fair, Ray C., 2002, Events that shock the market, Journal of Business, 75, 713731.

Fecht, Falko, Kjell G. Nyborg, and Jörg Rocholl, 2008, Liquidity management and overnight rate calendar effects: Evidence from German banks, North American Journal of Finance and Economics, 19, 7-21.

Fecht, Falko, Kjell G. Nyborg, Jörg Rocholl, Jiri Woschitz, 2015, Collateral, central bank repos, and systemic arbitrage, Working paper, University of Zurich and Swiss Finance Institute.

Flannery, Mark J. and Aris A. Protopapadakis, 2002, Macroeconomic factors do influence aggregate stock returns, Review of Financial Studies, 15, 751-782.

Fleming, Michael J. and Eli M. Remolona, 1997, What moves the bond market?, Federal Reserve Bank of N.Y. Economic Policy Review, 3, 31-50.

Friedman, Milton, 1970, A theoretical framework of monetary analysis, Journal of Political Economy, 78, 193-238.

Gabrieli, Silvia and Co-Pierre Georg, 2014, A network view on interbank market freezes, Discussion paper 44, Deutsche Bundesbank.

Gorton, Gary and Andrew Metrick, 2010, Haircuts, Federal Reserve Bank of St.Louis Review, 92, 507-519.

Gorton, Gary and Andrew Metrick, 2012, Securitized banking and the run on repo, Journal of Financial Economics, 104, 425-451.

Hamilton, James D., 1996, The daily market for federal funds, Journal of Political Economy, 104, 26-56.

Hamilton, James D., 1997, Measuring the liquidity effect, American Economic Review, 87, 80-97.

Hawkins, John, 2003, Central bank balance sheets and fiscal operations, BIS Papers 20, 71-83.

Heider, Florian and Marie Hoerova, 2009, Interbank lending, credit-risk premia and collateral, International Journal of Central Banking, 5, 1-39. 
Heider, Florian, Marie Hoerova, and Cornelia Holthausen, 2009, Liquidity hoarding and interbank market spreads: The role of counterparty risk, Working paper 1126, European Central Bank.

Jeanne, Olivier and Lars E.O. Svensson, 2007, Credible commitment to optimal escape from a liquidity trap: The role of the balance sheet of an independent central bank, American Economic Review, 97, 474-490.

Jordan, Thomas J., 2012, Some lessons for monetary policy from the recent financial crisis, International Journal of Central Banking, 8, 289-292.

Jordan, Bradford D. and Susan D. Jordan, 1997, Special repo rates: An empirical analysis, Journal of Finance, 52, 2051-2072.

Kashyap, Anil K. and Jeremy C., Stein, 2000, What do a million observations on banks say about the transmission of monetary policy?, American Economic Review, 90, 407-428.

Kiyotaki, Nobuhiro and John Moore, 1997, Credit cycles, Journal of Political Economy, 105, 211-248.

Knot, Klaas, 2013, Central bank independence and unconventional monetary policy: Challenges for the ECB, Speech at the Bank of Mexico international conference.

Krishnamurthy, Arvind, Stefan Nagel, and Dmitry Orlov, 2014, Sizing up repo, Journal of Finance, 69, 2381-2417.

Mancini, Loriano, Angelo Ranaldo, and Jan Wrampelmeyer, 2014, The euro interbank repo market, Working paper 1316, University of St.Gallen, School of Finance.

Miles, David and Jochen Schanz, 2014, The relevance or otherwise of the central bank's balance sheet, Journal of International Economics, 92, 103-116.

Nautz, Dieter and Christian J. Offermanns, 2007, The dynamic relationship between the euro overnight rate, the ECB's policy rate and the term spread, International Journal of Finance and Economics, 12, 287-300.

Nyborg, Kjell G., 2011, Stabilisierung der Euro-Zone durch Besicherung von Bonds, "Neue Zürcher Zeitung," http://www.nzz.ch/aktuell/startseite/ stabilisierung-der-euro-zone-durch-besicherung-von-bonds-1.11928023, August 8.

Nyborg, Kjell G., 2015, Collateral frameworks: The open secret of central banks, Book manuscript, University of Zurich and Swiss Finance Institute. 
Nyborg, Kjell G., Ulrich Bindseil, and Ilya A. Strebulaev, 2002, Bidding and performance in repo auctions: Evidence from ECB open market operations, Working paper 157, European Central Bank.

Nyborg, Kjell G. and Per Östberg, 2014, Money and liquidity in financial markets, Journal of Financial Economics, 112, 30-52.

Nyborg, Kjell G. and Ilya A. Strebulaev, 2001, Collateral and squeezing of liquidity in fixed rate tenders, Journal of International Money and Finance, 20, 769-792.

Paul, Ron, 2009, End the Fed, Grand Central Publishing, New York.

van Rixtel, Adrian and Gabriele Gasperini, 2013, "Financial crises and bank funding: Recent experience in the euro area," BIS Working paper 406.

Rösler, Cornelia, 2015, Frictions in the interbank market: Evidence from volumes, Working paper, University of Zurich and Swiss Finance Institute.

Sims, Christopher A., 2004, Fiscal aspects of central bank independence, European Monetary Integration, Chapter 4, 103-116, H.W. Sinn, M. Widgrén, and M. Köthenbürger, eds., MIT Press, US.

Singh, Manmohan, 2013, The changing collateral space, Working paper 25, International Monetary Fund.

Singh, Manmohan and Peter Stella, 2012, Money and collateral, Working paper 25, International Monetary Fund.

Skeie, David R., 2008, Banking with nominal deposits and inside money, Journal of Financial Intermediation, 17, 562-584.

Stella, Peter, 1997, Do central banks need capital?, Working paper 83, International Monetary Fund.

Stella, Peter, 2005, Central bank financial strength, transparency, and policy credibility, Staff paper 52, International Monetary Fund.

Tobin, James, 1980, Redefining the aggregates: Comments on the exercise, in Measuring the Money Aggregates: Compendium of Views Prepared by the Subcommittee on Domestic Monetary Policy of the House Committee on Banking, Finance, and Urban Affairs, 96th Congress, 2nd Session, Washington DC.

White, Lawrence J., 2010, The credit rating agencies, Journal of Economic Perspectives, 24, 211-226. 
Table 1: Eurosystem haircuts for marketable collateral from October 1, 2013

The information in this table was still in force as of January 31, 2015.

Sources: This is taken from Nyborg (2015), which contains additional information regarding haircuts for non-marketable collateral. The main original source is ECB (2013/35). The haircuts apply from November 1, 2013 for own-use covered bonds.

Notes: $(\dagger)$ This relates to haircuts of ABSs with a second-best rating below A- that fulfill certain additional requirements (see ECB, 2013/36). $\left({ }^{a}\right)$ Except ABSs backed by residential mortgages or loans to SMEs issued before June 20, 2012 that do not fulfill certain standard eligibility criteria, but have a credit quality of at least BBB-. These have a haircut of $22 \%$ (see ECB, 2013/36). The following notes are as reported in ECB (2013/35, ANNEXES 1 and 2) and ECB (2011/14, Table 6): ${ }^{(1)}$ In general, the issuer classification determines the liquidity category. However, all asset-backed securities are included in category $\mathrm{V}$, regardless of the classification of the issuer, and jumbo covered bank bonds are included in category II, while traditional covered bank bonds, other covered bank bonds and other debt instruments issued by credit institutions are included in category III and IV. (2) Debt certificates issued by the ECB and debt instruments issued by the NCBs prior to the adoption of the euro in their respective member state are included in liquidity category I. ${ }^{(3)}$ Only instruments with an issuing volume of at least EUR 1 billion, for which at least three market-makers provide regular bid and ask quotes, fall into the asset class of jumbo covered bank bonds. (4) Only marketable assets issued by issuers that have been classified as agencies by the ECB are included in liquidity category II. Marketable assets issued by other agencies are included in liquidity category III or IV, depending on the issuer and asset type. (5) Non-UCITS compliant covered bonds, including both structured covered bonds and multi-issuer covered bonds are included in liquidity category III. (6) Individual asset-backed securities, covered bank bonds (jumbo covered bank bonds, traditional covered bank bonds, and other covered bank bonds) and uncovered bank bonds that are theoretically valued in accordance with Section 6.5 of Annex I to Guideline ECB/2011/14 are subject to an additional valuation haircut. This haircut is directly applied at the level of the theoretical valuation of the individual debt instrument in the form of a valuation markdown of $5 \%$. Furthermore, an additional valuation markdown is applied to own-use covered bonds. This valuation markdown is $8 \%$ for own-use covered bonds in Credit Quality Steps 1 and 2, and 12\% for own-use covered bonds in Credit Quality Step 3 ["For these purposes, 'own-use covered bonds' means covered bank bonds issued by either a counterparty or entities closely linked to it, and used in a percentage greater than $75 \%$ of the outstanding notional amount by that counterparty and/or its closely linked entities" (ECB, 2013/35, p. 9)]. (7) Ratings as specified in the Eurosystem's harmonized rating scale, published on the ECB's website (www.ecb.europa.eu).

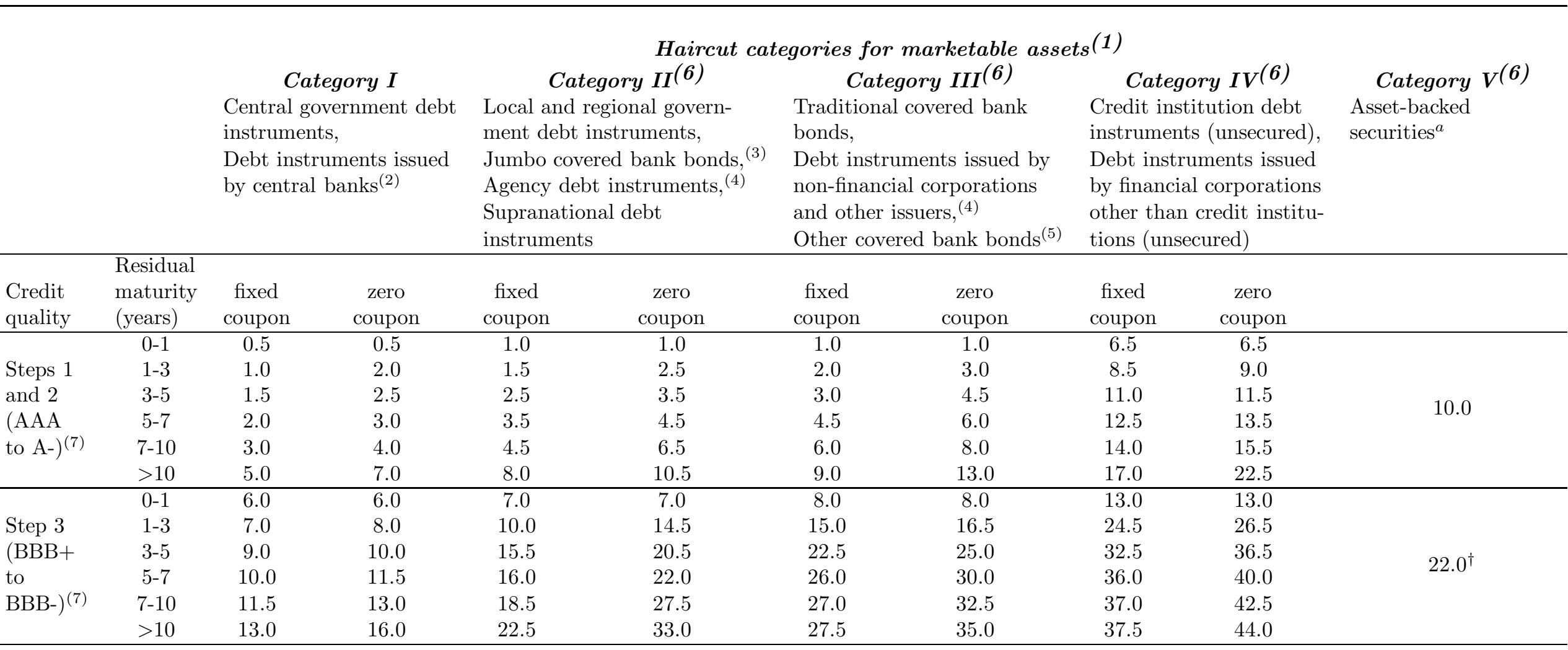


Table 1 - continued from previous page

Floating rate debt instruments:

Haircut is that applied to zero-to-one-year maturity buckets of fixed coupon instruments in liquidity and credit quality category to which the instrument is assigned.

Inverse floating rate debt instruments:

Haircuts applied to inverse floating rate debt instruments included in categories I to IV are the same but differ with respect to maturity bucket and credit quality categories. Haircuts as a function of residual maturity (residual maturity, haircut):

AAA to A-: $\quad 0-1,7.5 ; 1-3,11.5 ; 3-5,16.0 ; 5-7,19.5 ; 7-10,22.5 ;>10,28.0$. BBB+ to BBB-: $0-1,21.0 ; 1-3,46.5 ; 3-5,63.5 ; 5-7,68.0 ; 7-10,69.0 ;>10,69.5$.

Marketable assets denominated in foreign currency (yen, pounds sterling, and US dollars): there is an additional haircut which is applied in the form of a valuation markdown before applying the regular haircut. Valuation markdowns are as follows: Pounds sterling and US dollars: $16 \%$; Yen: $26 \%$.

Debt instruments issued by credit institutions and traded on non-regulated markets: same haircuts as for other marketable assets. 


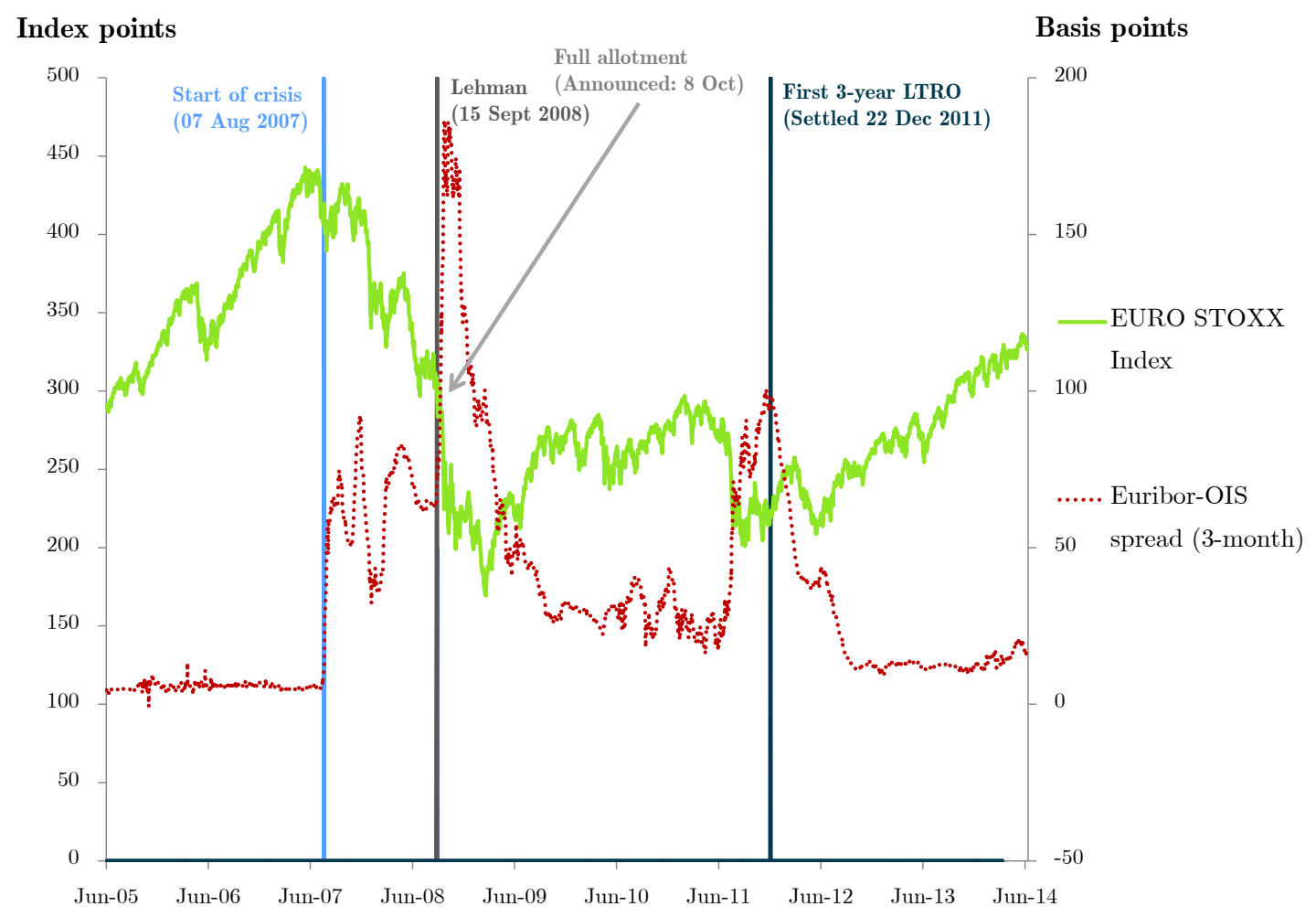

Figure 1: EURO STOXX Index and Euribor-OIS spread (3-month) Time period: June 20, 2005 - June 30, 2014

OIS is "Overnight Index Swap" and in this case, is the Eonia Swap. The spread is the difference between Euribor and the Eonia Swap and is in basis points.

Data source: http://www.stoxx.com/indices/index_information.html? symbol=SXXE and http://WWW.emmi-benchmarks.eu/ 


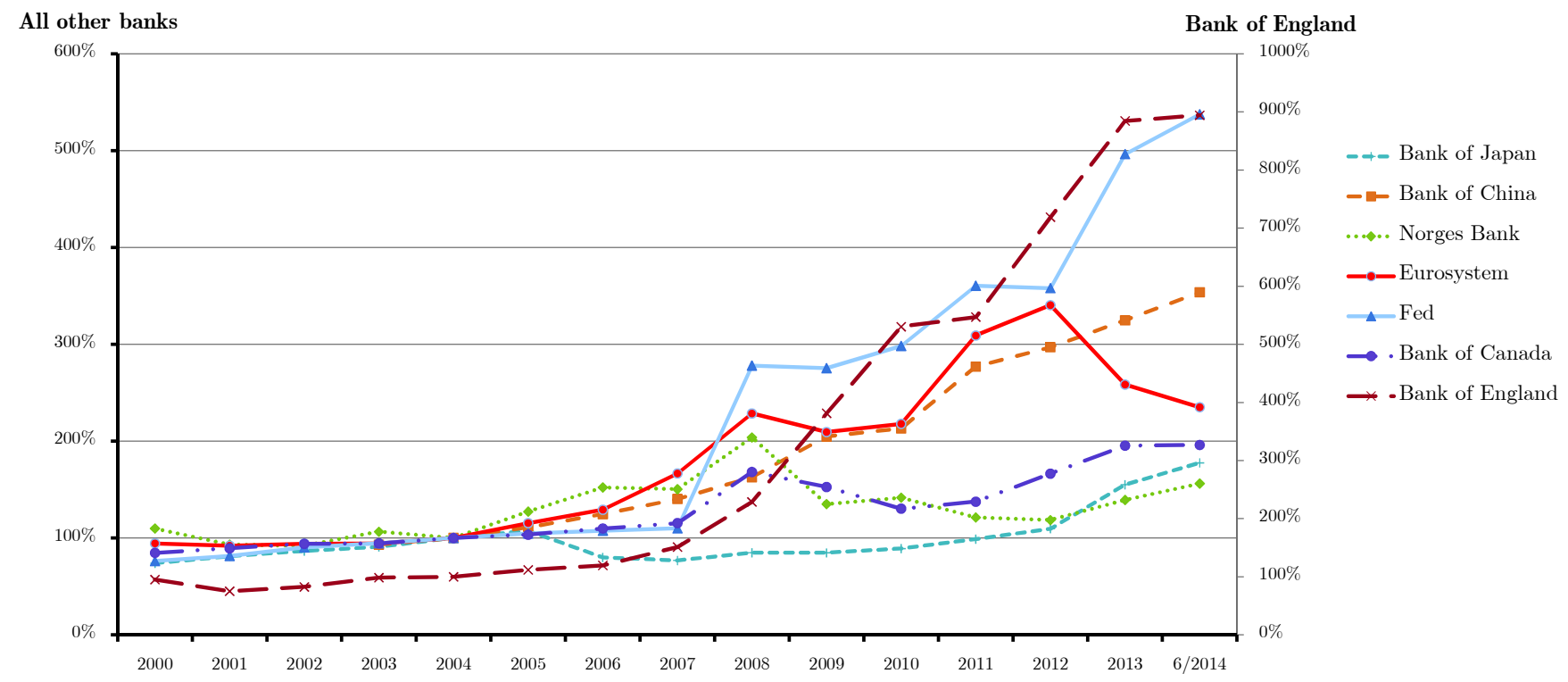

a) Growth of central banks' balance sheets over time

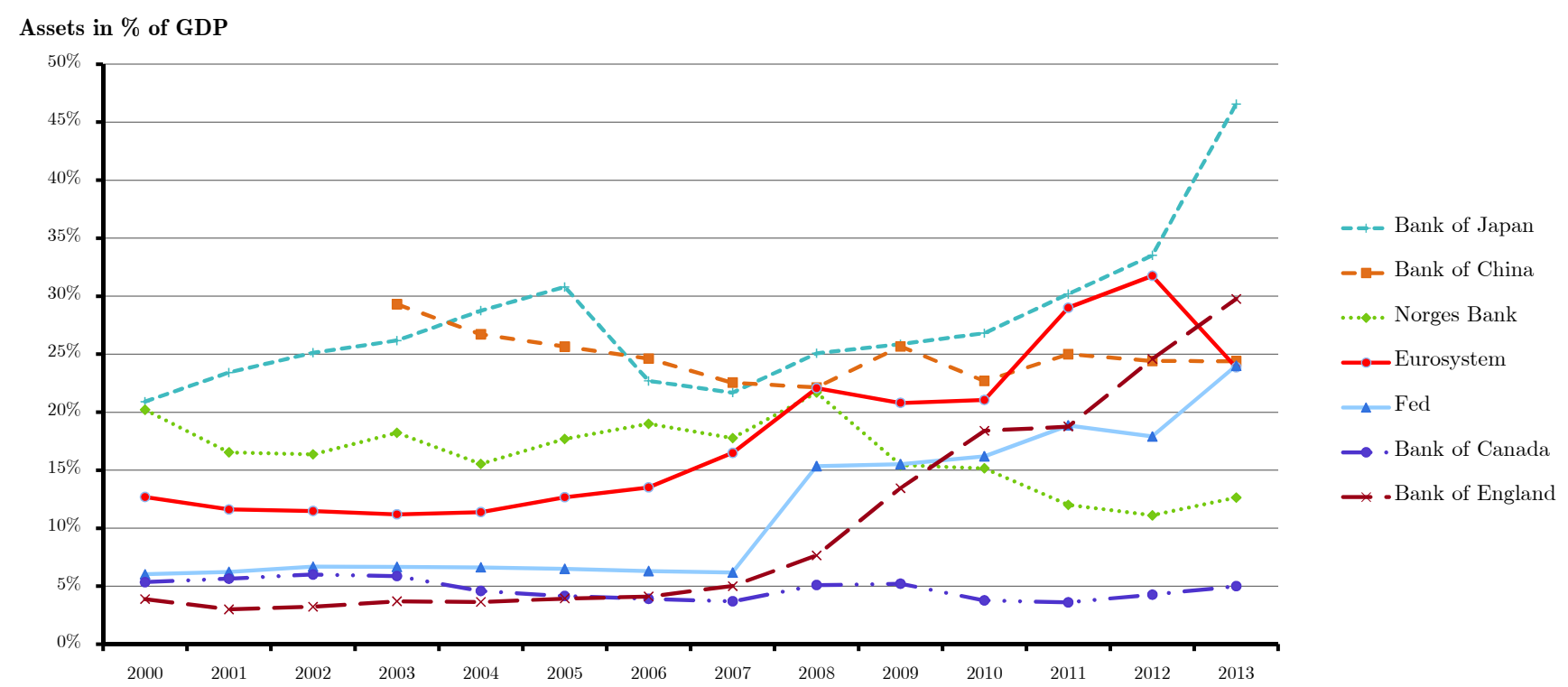

b) Central banks' balance sheets as a percentage of GDP

\section{Figure 2 : Central banks' balance sheets over time}

Figure 2a graphs the size of the Eurosystem's consolidated balance sheet over time as well as those of selected central banks. Numbers are normalized, with 2004 representing $100 \%$ for each bank. Figure $2 \mathrm{~b}$ graphs the balance sheet sizes as a percentage of GDP in the respective countries. For the Eurosystem, the aggregate GDP across euro area countries on a year by year basis is used. Datapoints are year end from 2000 - 2013 and in (a) 6/2014 for all banks except Bank of China $(3 / 2014)$. Data source: Balance sheet statistics are from the respective central banks' web-pages. GDP data is from the World Bank, Eurostat, and the central banks' web-pages. 


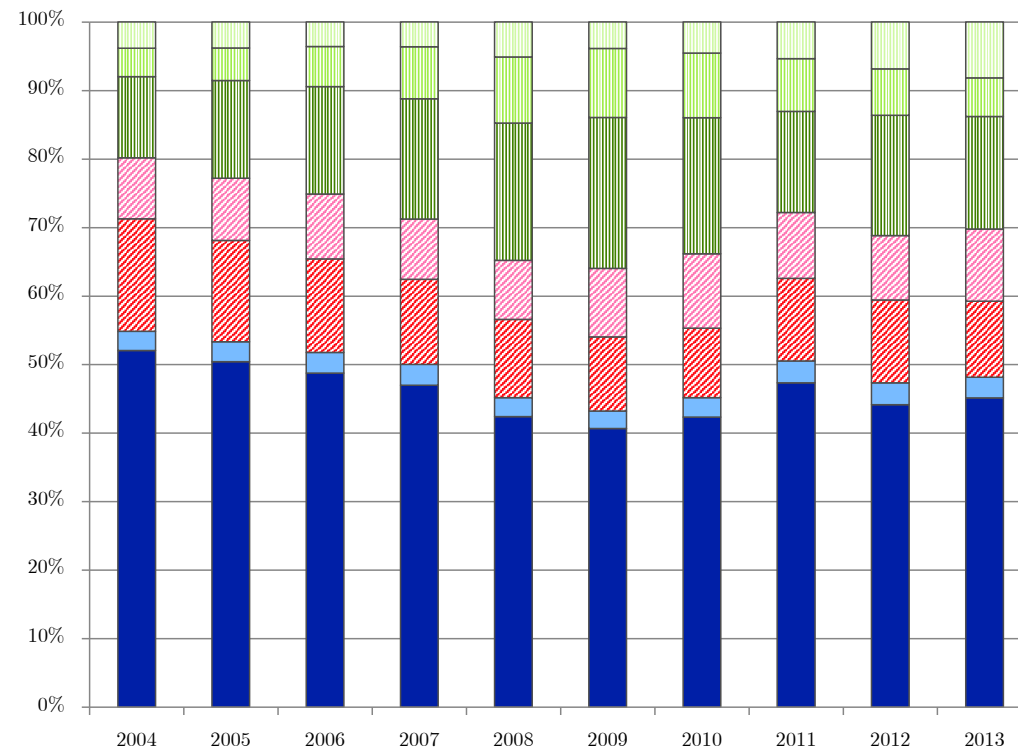

a) Eligible marketable asset class as \% of total eligible marketable assets

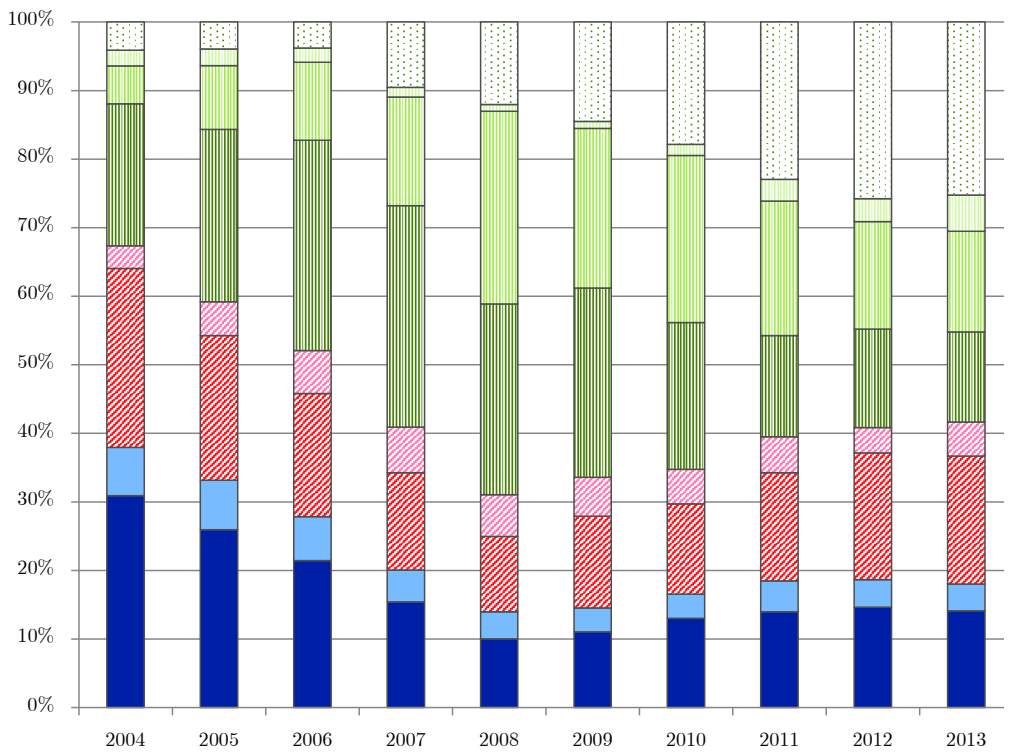

b) Used collateral (class as \% of total used collateral)
Non-marketable

$\square$ Other marketable assets

四 Asset-backed securities

血 Uncovered bank bonds

圆 Corporate bonds

圆 Covered bank bonds

$\square$ Regional government securities

Central government securities

\section{Figure 3 : Eligible assets and collateral used}

Figure 5a on the left shows eligible marketable assets in each collateral class as a percentage of the total eligible marketable assets per year. Amounts are nominal in EUR billion, averages of end of month data over each time period shown. For the years 2012 and 2013 ECB shows quarterly data (see ECB webpage, data source given below). Figure 5a shows yearly averages of ECB's quarterly data.

Figure $5 \mathrm{~b}$ on the right shows the amount of used collateral in each collateral class as a percentage of the total used collateral per year. This includes non-marketable assets, which are not part of ECB's eligible asset list. Amounts are after valuation and haircuts in EUR billion, averages of end of month data over each time period shown. Similarly to the eligible assets, ECB shows quarterly data for the years 2012 and 2013 (see ECB webpage, data source given below). Figure 5b shows yearly averages of ECB's quarterly data.

In general for both Figures $5 \mathrm{a}$ and $5 \mathrm{~b}$ data are compiled by the ECB for quarterly reference periods. Past data may be revised, e.g., as a result of methodological changes in the compilation of the source data (see ECB webpage, data source given below).

Data source: ECB webpage; collateral data from February 14, 2014; http://www.ecb.europa.eu/paym/coll/html/ index.en.html; downloaded on March 20, 2014. 


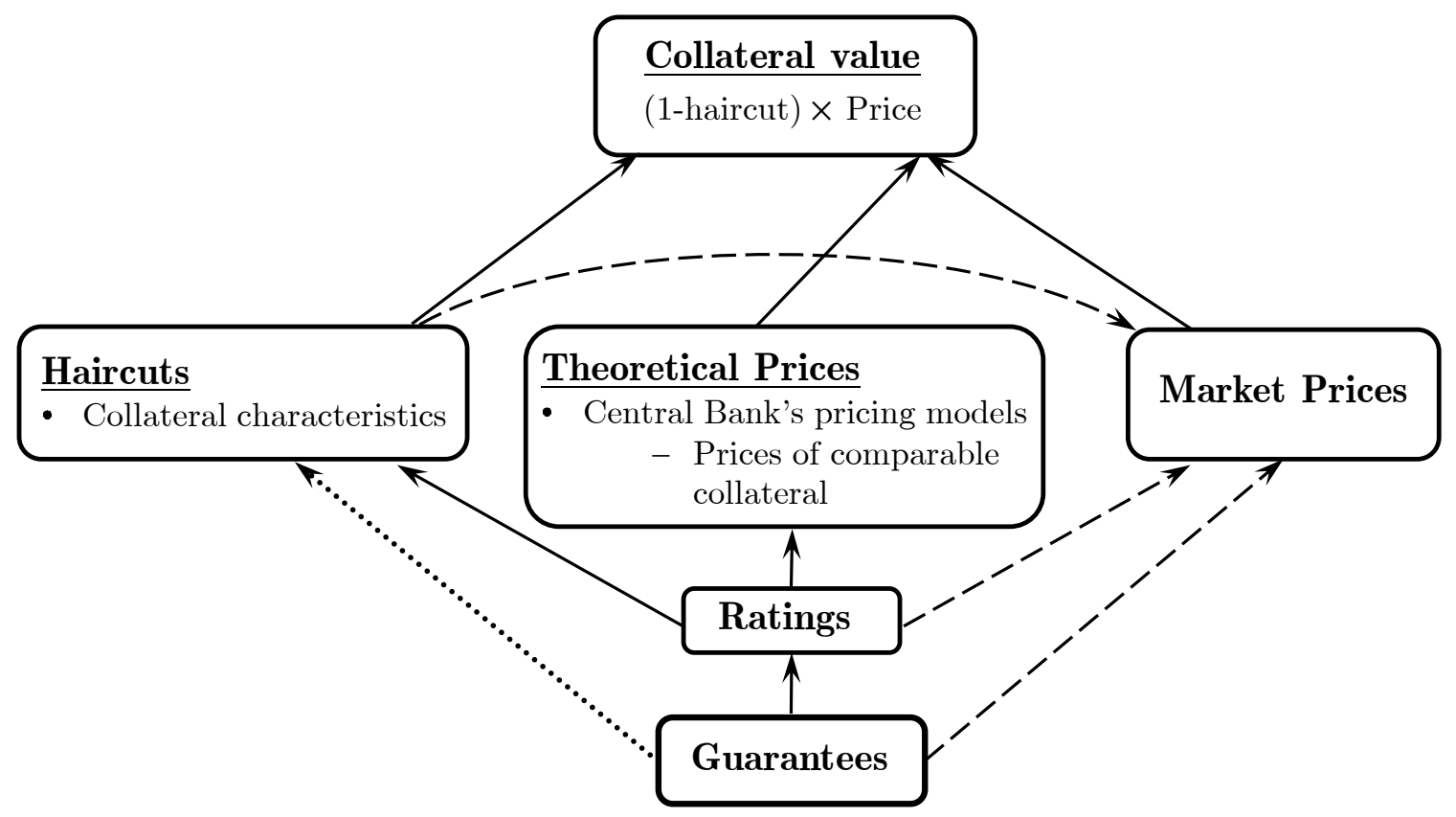

Figure 4: Determination of collateral values in the collateral framework Solid lines and boxes indicate features and elements of the collateral framework. Dashed lines point to variables that may influence market prices and, thereby, collateral values indirectly. The dotted line indicates that guarantees can influence haircuts directly. 


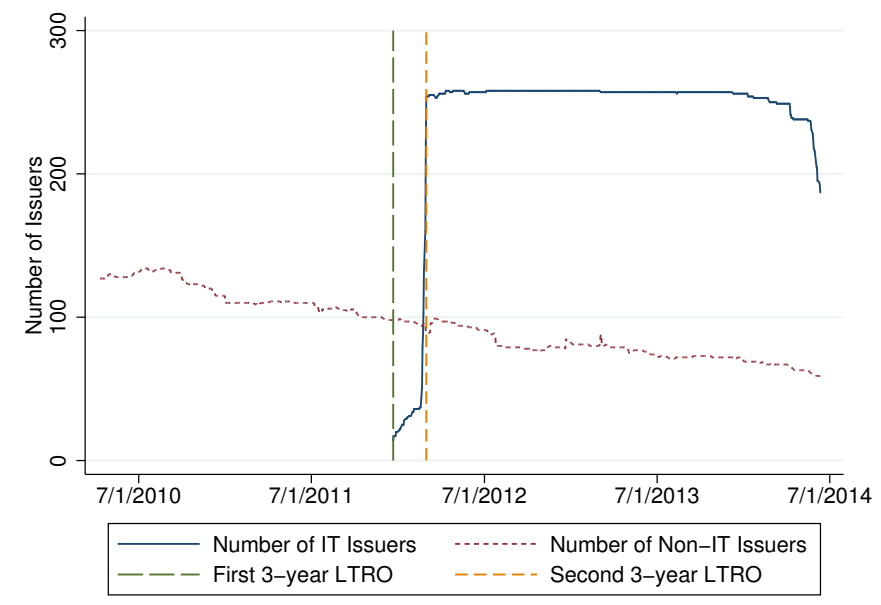

a) Credit institutions with government guarantees

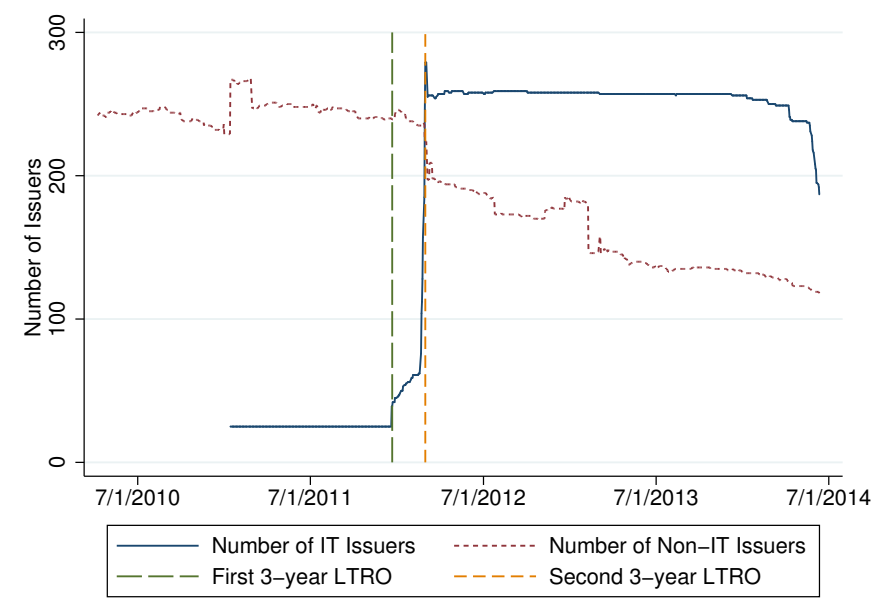

c) All issuers with government guarantees

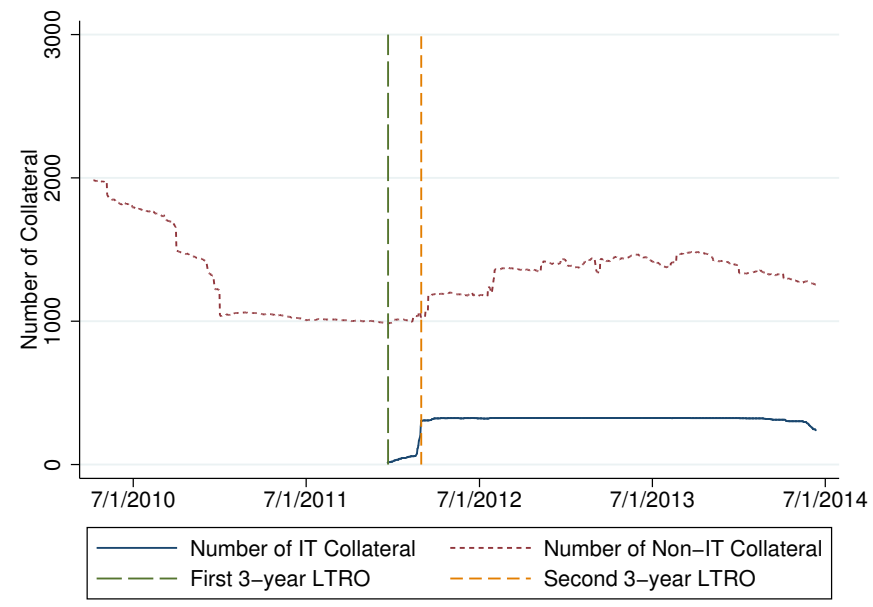

b) Credit institution collateral with government guarantees

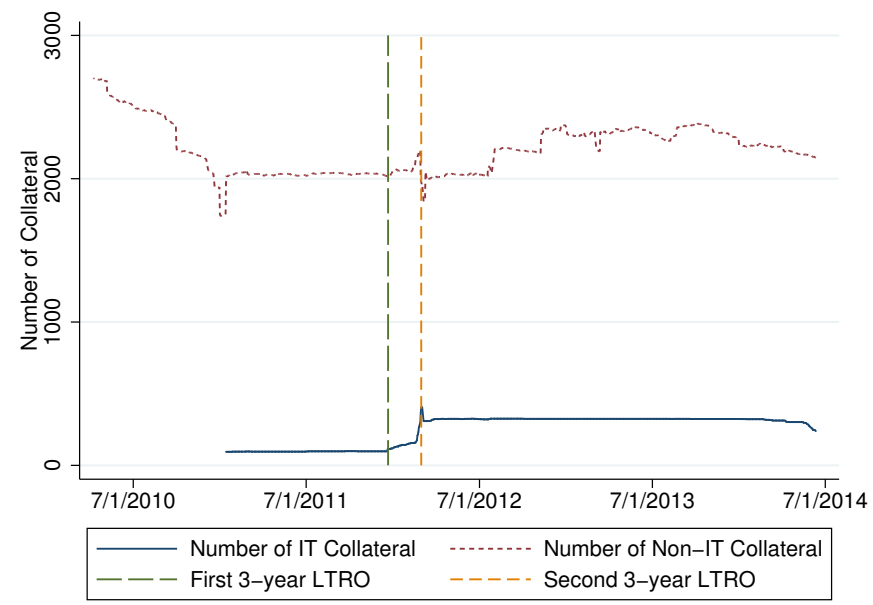

d) All issuers' collateral with government guarantees

\section{Figure 5 : Number of government guaranteed issuers and collateral}

Time period: April 8, 2010 - June 11, 2014

These figures graph the number of issuers with government (central, regional, local) guaranteed collateral as well as the number of such collateral over time on the Eurosystem's public list of eligible collateral. Figures $4 \mathrm{a}$ and $4 \mathrm{~b}$ contain the graphs for credit institutions only, while Figures $4 \mathrm{c}$ and $4 \mathrm{~d}$ cover all issuers and collateral. Separate graphs are provided for Italian (IT) and non-Italian (Non-IT) issuers and issues. The vertical lines represent the two three-year LTROs, held on December 21, 2011 and February 29, 2012, respectively.

Data source: http://www.ecb.europa.eu/paym/coll/assets/html/list.en. html 


\section{swiss : finance: institute}

c/o University of Geneva

40 bd du Pont d'Arve

1211 Geneva 4

Switzerland

$\mathrm{T}+41223798471$

F +41 223798277

RPS@sfi.ch

www.SwissFinanceInstitute.ch 